\title{
Hydrogeochemical Characteristics and Genesis Model of Jinjiang and Julong Hot Springs in Changbai Mountain, Northeast China
}

\author{
Baizhong Yan $\mathbb{D}^{1,2,3,4}$ Xiujuan Liang $\mathbb{D}^{1},{ }^{1}$ and Changlai Xiao $\mathbb{D}^{1}$ \\ ${ }^{1}$ Key Laboratory of Groundwater Resources and Environment, Ministry of Education and Key Laboratory of Water Resources and \\ Aquatic Environment, College of Environment and Resources, Jilin University, Changchun 130021, China \\ ${ }^{2}$ School of Water Resources \& Environment, Hebei GEO University, Shijiazhuang 050031, China \\ ${ }^{3}$ Hebei Province Key Laboratory of Sustained Utilization \& Development of Water Resources, Shijiazhuang 050031, China \\ ${ }^{4}$ Hebei Province Collaborative Innovation Center for Sustainable Utilization of Water Resources and Optimization of \\ Industrial Structure, Shijiazhuang 050031, China
}

Correspondence should be addressed to Xiujuan Liang; lax64@126.com

Received 21 June 2018; Accepted 28 August 2018; Published 28 November 2018

Academic Editor: Mohammad Sarmadivaleh

Copyright () 2018 Baizhong Yan et al. This is an open access article distributed under the Creative Commons Attribution License, which permits unrestricted use, distribution, and reproduction in any medium, provided the original work is properly cited.

\begin{abstract}
Changbai Mountain in China has been explored as a potential area for its rich hot springs including the Jinjiang and Julong hot spring groups. The hydrogeochemical characteristics and conceptual genesis models of the Jinjiang and Julong hot springs were evaluated by hydrogeochemical analysis, isotope analysis, rock sample analysis, hydrogeochemistry simulation, and geophysical exploration method. The results showed that $\mathrm{HCO}_{3}{ }^{-}$and $\mathrm{Na}^{+}$were the most abundant anion and cation in the hot springs, and the hydrochemical type was $\mathrm{Na}-\mathrm{HCO}_{3}$. And the hot springs are enriched with trace components such as $\mathrm{H}_{2} \mathrm{SiO}_{3}$ and $\mathrm{Sr}$. The major gas composition of the Jinjiang hot springs and Julong hot springs were $\mathrm{CO}_{2}, \mathrm{~N}_{2}$, and $\mathrm{CH}_{4}$, which were derived from the mantle. The chemical compositions were produced by feldspar and pyroxene mineral hydrolysis. The recharge source of the hot springs was atmospheric precipitation and was also influenced by evaporation, and the genetic models for the Jinjiang hot springs and Julong hot springs were as follows: the heat source of both was a magma body and heat was mainly migrated in the form of thermal conduction. The cap rocks were both composed of trachyte of Baitoushan formation, basalt of Junjianshan formation, and rhyolitic pyroclastic rocks of Changbai formation. The geothermal reservoir of both hot springs was a fracture zone with the lithology of volcanic breccia, sand, and gravel and volcanic breccia and marble, respectively.
\end{abstract}

\section{Introduction}

Geothermal resources are being researched and developed as renewable and clean energy all over the world because of its rich reservoir, renewable resources, reliability, and environmental acceptability [1]. Hydrogeochemical composition is an important indicator for the quality evaluation of geothermal resources that reflects the formation evolution process, interaction between geothermal fluid and rock, and geothermal fluid circulation condition [2]. The hydrogeochemical compositions also have the vital role for corrosion and scaling, geothermal reservoir temperature evaluation, and geothermal fluid uses. In recent decades, many countries have conducted much research in geothermal water resource exploitation.

Changbai Mountain is located in the east of the Songliao Basin, China, and is a tectonically and volcanically active area. Due to the previous volcanic activities, the region is rich in geothermal springs, which are discharged at different altitudes. The monitoring of geothermal fluid of Changbai Mountain began in 1985, and the main monitoring compositions include $\mathrm{CO}_{2}, \mathrm{~N}_{2}, \mathrm{He}, \mathrm{H}_{2}, \mathrm{O}_{2}$, and $\mathrm{CH}_{4}$ which were associated with volcanic activities [3]. Tianchi volcano is one of the famous active volcanoes in China. Its eruptive history included early shield-forming, middle cone construction, and late ignimbrite-forming eruptions in three stages [4]. 
The eruptive products were alkali and tholeiitic basalts, trachyte and comendite lavas, and pyroclastic equivalents [5]. So what are the hydrogeochemical characteristics of the hot springs and what are the sources of the hydrogeochemical compositions on the complex geothermal geological environments? Solving these problems are vital for the development and utilization of geothermal water resources.

The heat source, heat reservoir, heat conduction channel, and cap rock are four basic elements for the geothermal water system [6]. Study of the geothermal water system model is an important means to reveal the formation and distribution of a geothermal field. At present, the geothermal water system model mainly includes a simple conceptual model, analytical model, lumped parameter model, and distributed parameter model [7]. The geothermal field characteristics of the New Zealand Wairakei-Tauhara were revealed by a simple concept model. The hot water welled up to the surface through the NESW fracture, and the heat reservoir temperature ranged from 260 to $300^{\circ} \mathrm{C}$ [8]. Based on two-dimensional groundwater flow theory, the heat conduction model of Leibnitzer geothermal field was established by using FEFLOW software [9]. The heat sources of the Obama geothermal water system in Japan were studied by three-dimensional numerical model [10].

Geothermal exploration is the most direct method to probe and identify geothermal resources, which can be used to deeply and fully understand the geothermal resource forming process [11]. Geophysical exploration for the subsurface geothermal reservoir began in early 1980 which was a geothermal exploration, mainly employing shallow electrical resistivity surveys [12]. Nowadays, the common geophysical exploration methods are the geoelectrical method, thermal method, seismic method, magnetic measurement method, and gravimetric method [13]. Newman et al. [14] expounded the characteristics of the Coso geothermal field and the relationship with tectonic fissures by using $3 \mathrm{D}$ magnetotelluric exploration method.

At present, the developed geothermal springs of Changbai Mountain were utilized for balneology and spa purposes. Most of the geothermal spring resources are still not developed. Among the hot springs, the Julong springs and Jinjiang springs have the highest flow quantity and temperature in this region. The distribution areas and flow quantity of the Julong springs and Jinjiang springs are, respectively, $3317.50 \mathrm{~m}^{2}$ and $210.0 \mathrm{~m}^{2}$ and $6455.48 \mathrm{~m}^{3} / \mathrm{d}$ and $578.8 \mathrm{~m}^{3} / \mathrm{d}$. Nowadays, the local government has enhanced the development of the geothermal springs, and some geothermal water diversion projects were established. But the hydrogeochemical characteristics, recharge sources, and genesis model of the Julong springs and Jinjiang springs are not clear. Therefore, in order to develop, use, and protect the geothermal springs, studying the hydrogeochemical characteristics, recharge sources, and genesis model of geothermal springs is urgently needed. In this study, the Julong springs and Jinjiang springs were comprehensively analyzed via sampling and monitoring of geothermal spring water for hydrogeochemical characteristics and genesis model, isotope analysis, and geophysical exploration. The results of the research would promote the development and utilization of geothermal resources and enrich the genesis mechanism of the geothermal system.

\section{Study Area and Volcano Geology}

Julong springs and Jinjiang springs are located in the Changbai Mountain basalt area in the east of Jilin Province. Geographical coordinates are located in the north latitude of $41^{\circ} 23^{\prime}-42^{\circ} 35^{\prime}$ and east longitude of $127^{\circ} 15^{\prime}-129^{\circ} 00^{\prime}$. The area has a temperate continental monsoon climate with an annual average temperature of $3.5^{\circ} \mathrm{C}$. According to Changbai Mountain weather stations, the annual average precipitation is $1332.6 \mathrm{~mm}$, much of which occurs during the period from June to September.

The geological groups in the Julong spring and Jinjiang spring areas mainly include Proterozoic Laoling formation $\left(\mathrm{Pt}_{1} \mathrm{z}\right)$, Triassic Changbai formation $\left(\mathrm{T}_{3} \mathrm{c}\right)$, Cenozoic Pleistocene Junjianshan formation $\left(\mathrm{Q}_{1} \mathrm{pj}\right)$, Baitoushan formation $\left(\mathrm{Q}_{2} \mathrm{~b}\right)$, and Cenozoic Holocene Bingchang formation $\left(\mathrm{Q}_{4} \mathrm{bc}\right)$. The lithology of the Laoling formation $\left(\mathrm{Pt}_{1} \mathrm{z}\right)$ is dolomitic marble, with an average thickness of $467 \mathrm{~m}$, the lithology of the Changbai formation $\left(\mathrm{T}_{3} \mathrm{c}\right)$ is rhyolite and rhyolitic pyroclastic rocks and the average thickness is $1300 \mathrm{~m}$, the lithology of the Junjianshan formation $\left(\mathrm{Q}_{1} \mathrm{pj}\right)$ is basalt and olivine basalt and the average thickness is $189 \mathrm{~m}$, the lithology of the Baitoushan formation $\left(\mathrm{Q}_{2} \mathrm{~b}\right)$ is trachyte and tuffaceous trachyte and the average thickness is about $130 \mathrm{~m}$, and the lithology of the Bingchang formation $\left(\mathrm{Q}_{4} \mathrm{bc}\right)$ is alkaline pumice and the average thickness is about $51.5 \mathrm{~m}$ (Figure 1).

The bedrock geology is composed of ancient metamorphic rocks, formed in the Archean-Proterozoic, and massive granite formed in the Mesozoic. The terrigeneous sediments were deposited in the Mesozoic, which was interrupted by intermediate to acid magmatic activities. In the Cenozoic, basalt magma was discharged from the upper mantle via the huge fault which led to the volcanic eruption and created a broad basalt platform. The Tianchi volcano region was the center of those volcanic activities. The bedrocks of the Julong hot springs are dolomitic marble of Laoling formation $\left(\mathrm{Pt}_{1} \mathrm{z}\right)$ and rhyolite of Changbai formation $\left(\mathrm{T}_{3} \mathrm{c}\right)$. The bedrocks of the Jinjiang hot springs are andesite of Changbai formation $\left(\mathrm{T}_{3} \mathrm{c}\right.$ ) (Figure 2).

\section{Methods}

3.1. Hot Spring Sample and Analysis. The Julong hot springs and Jinjiang hot springs were sampled in October of 2015 and analyzed for $\mathrm{pH}$, temperature, electrical conductivity (EC), inorganic chemical composition, metal elements, trace elements, and gas composition. The $\mathrm{pH}$ and EC were measured in situ by using a low-range $\mathrm{pH} / \mathrm{EC}$ tester (Hanna Combo Model HI98129, Beijing Hengtai Ruibo Technology Development Co. Ltd., Beijing, China) [15]. Temperature was measured in situ by thermometer. Bicarbonate concentration was determined by using titration against hydrochloric acid. Sulphate and nitrate concentrations were determined by using a spectrophotometer (V-1300, Macy China Instruments Inc., Beijing, China). Silicate was determined by using potassium fluorosilicate. Chloride ion was estimated by titration against a standard solution of $\mathrm{AgNO}_{3}$. Sodium, potassium, calcium, and 


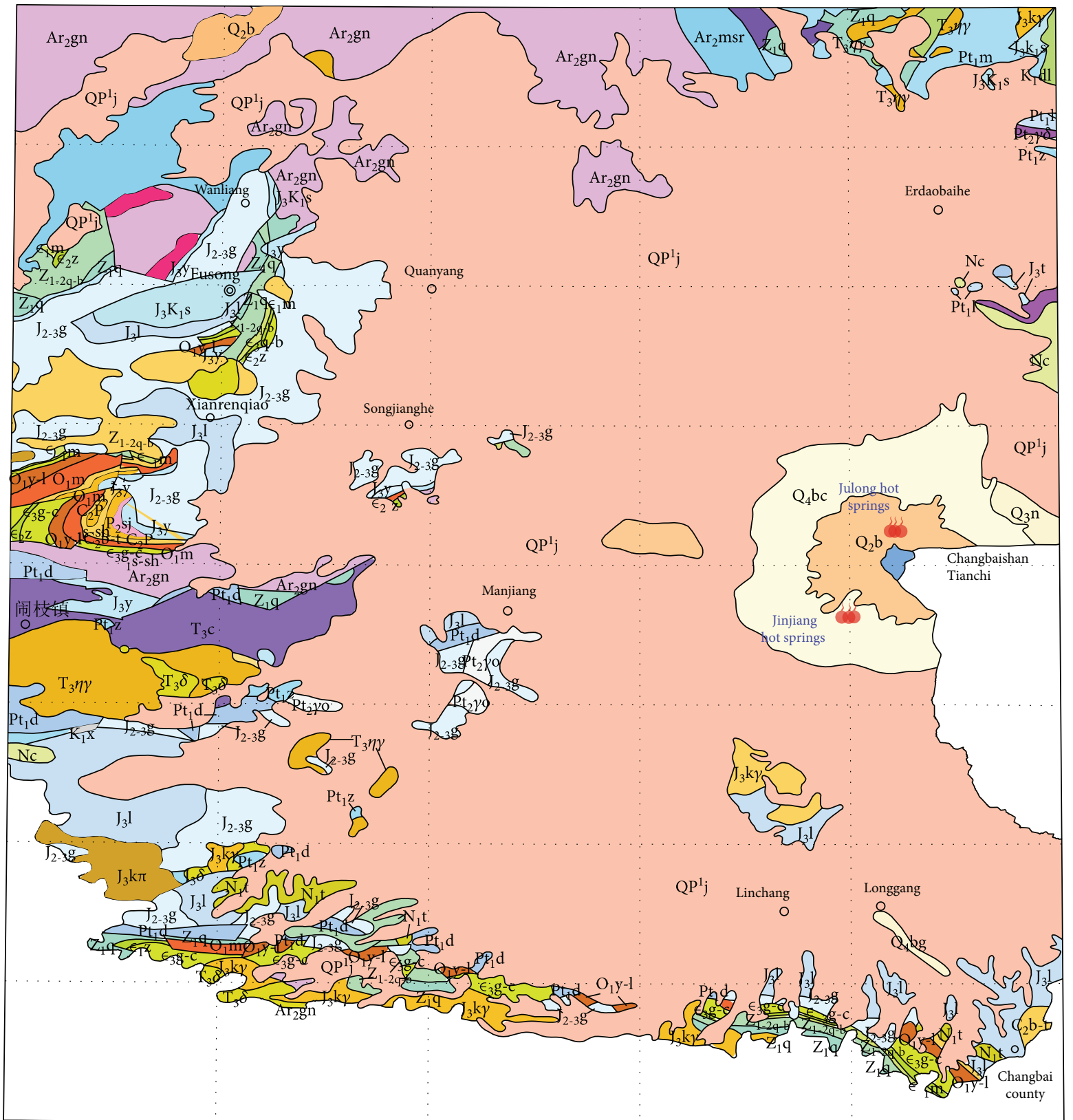

$\mathrm{Q}_{\mathrm{i}} \mathrm{b}$ Baguamiao Fm:alkali brecciated tuff and lava

\begin{tabular}{|c|c|}
\hline$Q_{4} b c c$ & Bingchang Fm:alkali pumice \\
\hline $\mathrm{Q}_{3} \mathrm{n}$ & Nanping Fm:tuff and brecciated tuff \\
\hline & Baitoushan Fm:trachyte,tuff and pumice \\
\hline & Junjianshan Fm:stomatal and laminated basalt \\
\hline 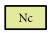 & Chuandishan Fm:olivine and stomatal basalt \\
\hline & Dalizi Fm: sandstone and siltstone \\
\hline \begin{tabular}{|l}
$I_{3} \mathrm{~K}$ \\
\end{tabular} & Shiren Fm:conglomerate, sandstone and mudstone \\
\hline$I_{13}$ & Tuntianying Fm:andesitic breccia and andesite \\
\hline & Linzitou Fm:tuffaceous conglomerate, sandstone and siltstone \\
\hline 5 & Yingzuilizi Fm:conglomerate, sandstone and siltstone \\
\hline \begin{tabular}{|l}
$I_{2}$ \\
\end{tabular} & Guosong Fm:conglomerate, sandstone and andesite \\
\hline & Changbai Fm:rhyolite, rhyolitic pyroclastic rock and andesite \\
\hline & Shanxi Fm and Shihezi Fm: siltstone, sandstone thin limestone \\
\hline & Benxi Fm and Taiyuan Fm:sandstone and siltstone and shale \\
\hline & Majiagou Fm:dolomitic limestone and leopard skin limestone \\
\hline & Yeli Fm and Liangjiashan Fm:dolomitic limestone and bambc \\
\hline
\end{tabular}

$\mathrm{G}_{\mathrm{g} B \mathrm{~B}-\mathrm{C}}$ Gushan Fm and Chaomidian Fm:siltstone and shale laminated limestone

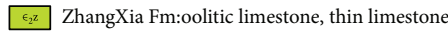

$\epsilon_{\mathrm{f}} \mathrm{m}$ Mantou Fm:dolomite,siltstone and silty shale

$Z_{1-2 a_{2}-\mathrm{b}}$ Badaojiang Fm, Wanlong Fm and Qiaotou Fm:limestone, sandstone, quartz sandstone $\mathrm{P}_{1} \mathrm{~d}$ Dalizi Fm:silk mica schist and thin marble

$\mathrm{Pt}_{1} 1$ Linjiang Fm:sericite, chlorite quartz schist and phyllite

$\mathrm{P}_{\mathrm{t}, \mathrm{z}}$ Zhenzhumen Fm:dolomitic marble

$\mathrm{Pt}_{1} \mathrm{~m}$ Mayihe Fm:plagioclase amphibolite and schist

$\mathrm{P}_{\mathrm{t}, \mathrm{h}}$ Huangchagou Fm:marble and slate

$A \mathrm{Ar}_{\mathrm{gn}}$ Mesoarchean potassium granite gneiss

$\mathrm{Ar}_{2} \mathrm{~ms}$ Neoarchean metamorphic plagioclase amphibolite rock

$\mathrm{T}_{3} \eta \mathrm{T}$ Late Permian monzonitic granite

$I_{3} \mathrm{k}_{\mathrm{k} p}$ Late Jurassic granite

$\mathrm{I}_{1} \mathrm{k}_{2}$ Early Jurassic diorite

$\mathrm{Pt}_{2} \mathrm{Oo}$ Mesoproterozoic plagioclase granite

Hot spring groups

Figure 1: Geological map of the Changbai Mountain area. 


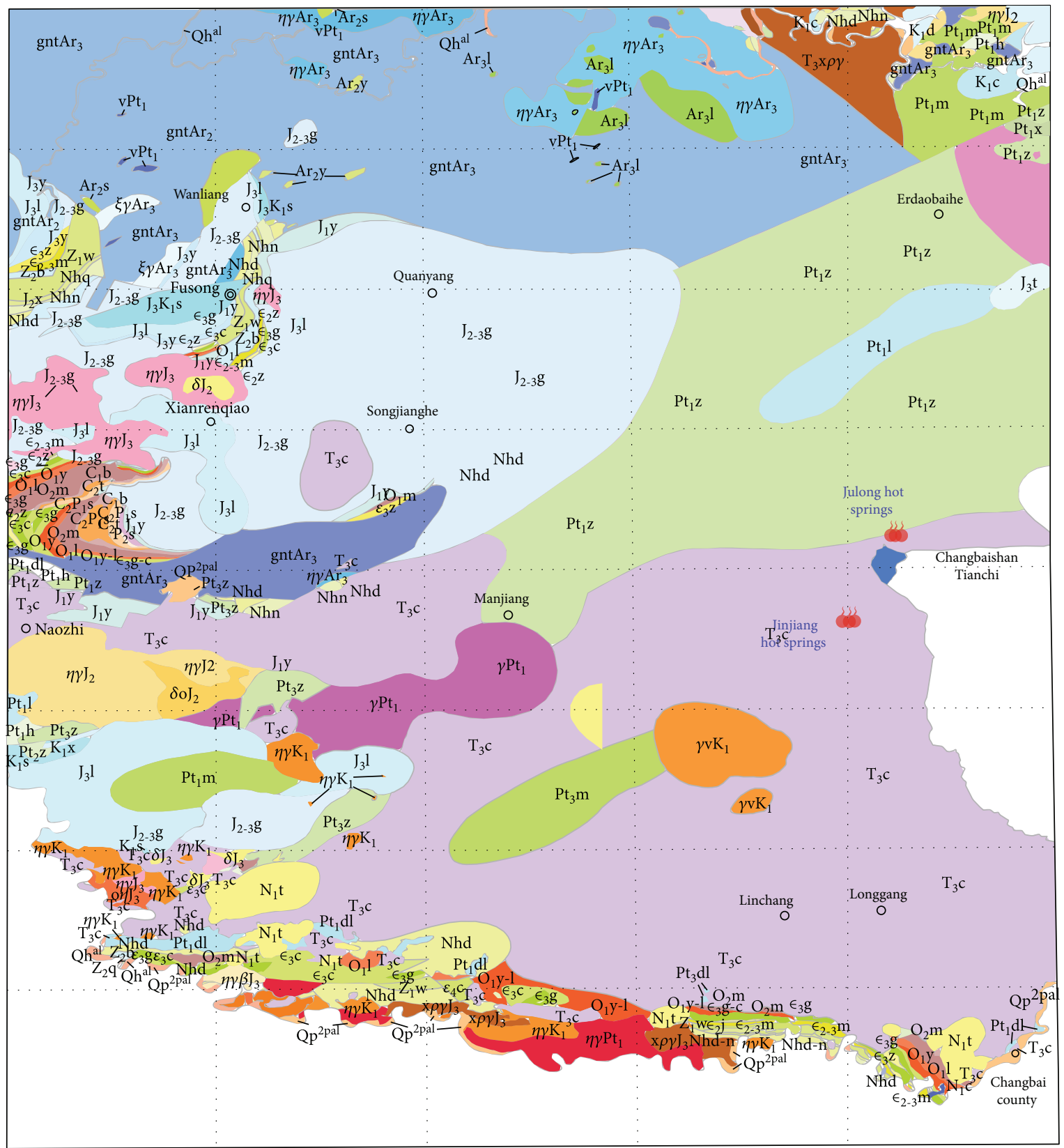

$\mathrm{K}_{\mathrm{I}} \mathrm{d}$ Dalizi Fm: sandstone and siltstone

$\mathrm{K}_{19}$ Quanshui Fm:andesite and andesitic agglomerate

$\mathrm{K}_{\mathrm{i}} \mathrm{c}$ Changcai Fm:conglomerate and tuffaceous sandstone

$\mathrm{K}_{1} \mathrm{x}$ Xiaonangou $\mathrm{Fm}:$ conglomerate and siltstone

$\mathrm{J}_{3} \mathrm{~K}_{1}$ Shiren Fm:conglomerate, sandstone and mudstone

$\mathrm{I}_{\mathrm{s}}$ Tuntianying Fm:andesitic breccia and andesite

${ }_{3} 1$ Linzitou Fm:tuffaceous conglomerate, sandstone and siltstone

T2.38 Guosong Fm:conglomerate, sandstone and andesit

$\mathrm{I}_{2} \mathrm{x}$ Xiaodonggou Fm:sandstone and conglomerate

${ }_{1, y}$ Yihe Fm:Tuffaceous conglomerate and sandstone

$T_{3, x}$ Xiaohekou Fm:Conglomerate and sandstone

Tuopangou Fm:breccia tuff, tuffaceous breccia,andesite

$T_{3}$, Changbai Fm:rhyolite, rhyolitic pyroclastic rock and andesite

$\mathrm{P}, \mathrm{s}]_{\mathrm{s}}$ Sunjiagou $\mathrm{Fm}$ :mudstone and silty mudstone

$\mathrm{P}_{2} \mathrm{~s}$ Shihezi Fm:Shale and sandstone

$\mathrm{C}_{2} \mathrm{P}_{1}$ S Shanxi Fm:gravel coarse sandstone, coarse sandstone and fine sandstone

C,b-t Benxi Fm and Taiyuan Fm:sandstone and siltstone and shale

$0, m$ Majiagou Fm:dolomitic limestone and leopard skin limestone

$0_{1},-1$ Yeli Fm and Liangjiashan Fm:dolomitic limestone and bamboo limestone

Gis:- Gushan Fm and Chaomidian Fm:siltstone and shale laminated limestone

ZhangXia Fm:oolitic limestone, thin limeston

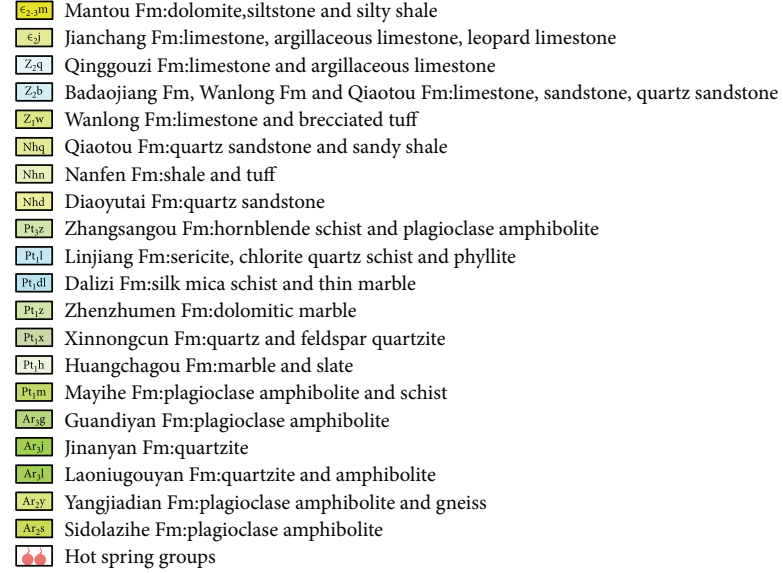

Figure 2: Bedrock geological map of the Changbai Mountain area. 
TABLE 1: Concentration of chemistry compositions on hydrogeochemistry simulation (mg/L).

\begin{tabular}{lccccccccccc}
\hline Water samples & $\mathrm{T}\left({ }^{\circ} \mathrm{C}\right)$ & $\mathrm{pH}$ & $\mathrm{K}^{+}$ & $\mathrm{Na}^{+}$ & $\mathrm{Ca}^{2+}$ & $\mathrm{Mg}^{2+}$ & $\mathrm{HCO}_{3}{ }^{-}$ & $\mathrm{SO}_{4}{ }^{2-}$ & $\mathrm{Cl}^{-}$ & $\mathrm{H}_{2} \mathrm{SiO}_{3}$ \\
\hline Rain samples & 12.00 & 8.01 & 0.31 & 0.20 & 9.96 & 0.19 & 17.99 & 3.34 & 5.26 & 2.03 \\
Jinjiang springs & 48.50 & 6.77 & 19.79 & 258.25 & 31.45 & 15.84 & 787.60 & 14.86 & 47.79 & 176.26 \\
Julong springs & 83.00 & 7.34 & 19.41 & 347.39 & 37.19 & 3.275 & 904.01 & 0.00 & 114.715 & 211.715 \\
\hline
\end{tabular}

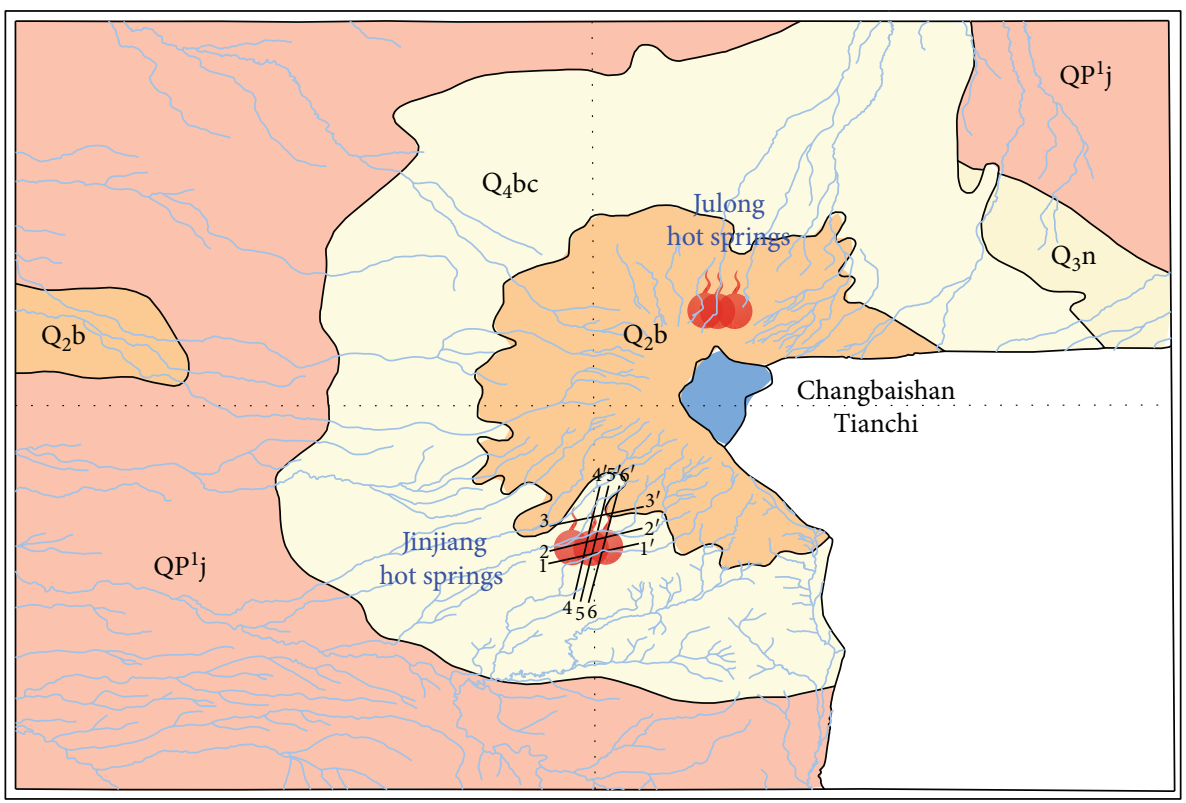

$\mathrm{Q}_{4} \mathrm{bc}$ Bingchang Fm:alkali pumice

$\mathrm{Q}_{2} \mathrm{~b}$ Baitoushan Fm:trachyte,tuff and pumice

$\mathrm{Q}_{1} \mathrm{pj}$ Junjianshan Fm:stomatal and laminated basalt

$\mathrm{Q}_{3} \mathrm{n}$ Nanping Fm:tuff and brecciated tuff $\checkmark$ Prospecting lines of high-density electrical

Hot spring groups

$\square$ River

Changbaishan Tianchi

FIGURE 3: Arrangement diagram of the prospecting lines of the high-density electrical method.

magnesium were determined by flame atomic absorption spectrophotometer (AA-6300, Shimadzu International Trading Ltd., Shimane, Japan). Other metallic and trace elements were also determined by flame atomic absorption spectrophotometer (AA-6300, Shimadzu International Trading Ltd., Shimane, Japan). The analytical precision for ion measurements was determined by calculating the ionic balance error, which is generally within $\pm 5 \%$. AquaChem software was used to determine the hydrogeochemical characteristics of spring waters [16].

Gas samples were collected by prevacuum collector method, and the gas samples were collected in the vacuumpacked bag. $\mathrm{CO}_{2}, \mathrm{He}, \mathrm{H}_{2}, \mathrm{O}_{2}$, and $\mathrm{N}_{2}$ were determined by using a gas chromatograph (SP-3420A, Beijing BeifenRuili Analytical Instrument Co. Ltd., China). The ratio value of ${ }^{3} \mathrm{He} /{ }^{4} \mathrm{He}$ was determined by mass spectrometer (Noblesse SFT).

3.2. Isotope Analysis. Stable isotope $\delta \mathrm{D}-\delta^{18} \mathrm{O}, \mathrm{C}$ isotopes, and noble gas isotopes $(\mathrm{Ne}, \mathrm{He})$ of the Julong hot springs and Jinjiang hot springs were detected to determine the sources of geothermal fluids. Two rain and snow water samples collected in the study area were also tested for stable isotope $\delta \mathrm{D}-\delta^{18} \mathrm{O} . \delta \mathrm{D}-\delta^{18} \mathrm{O}$ were determined by IRM-GC/MS (Agilent 5973, Shimadzu International Trading Ltd., Shimane, Japan); C isotopes were determined by stable isotope mass spectrometer (DELTA plus XP); noble gas isotopes were determined by noble gas isotope mass spectrometer (Noblesse SFT).

3.3. Rock Sample and Analysis. In order to determine the microstructure, element types, and mineral compositions of the rocks of the Julong hot springs and Jinjiang hot springs, four rock samples were precisely determined by scanning electron microscope (JSM-6700F on Windows NT) and X-ray diffraction (XRD, YST-I). For the SEM and EDS analyses, the rock samples are prepared into thin sections, $0.2 \times 0.2 \times 0.03 \mathrm{~mm}^{3}$, and for the XRD analysis, the rock samples are prepared into powder.

3.4. Hydrogeochemistry Simulation. Albite, potassium feldspar, pyroxene, silica, calcite, calcium montmorillonite, kaolinite, fluorite, illite, and gypsum possible mineral phases were selected to analyze the source of hot spring chemical compositions. The geochemical modelling programme PHREEQC [17] was used to calculate the possibility of mineral reaction in the Julong and Jinjiang hot spring water. The 


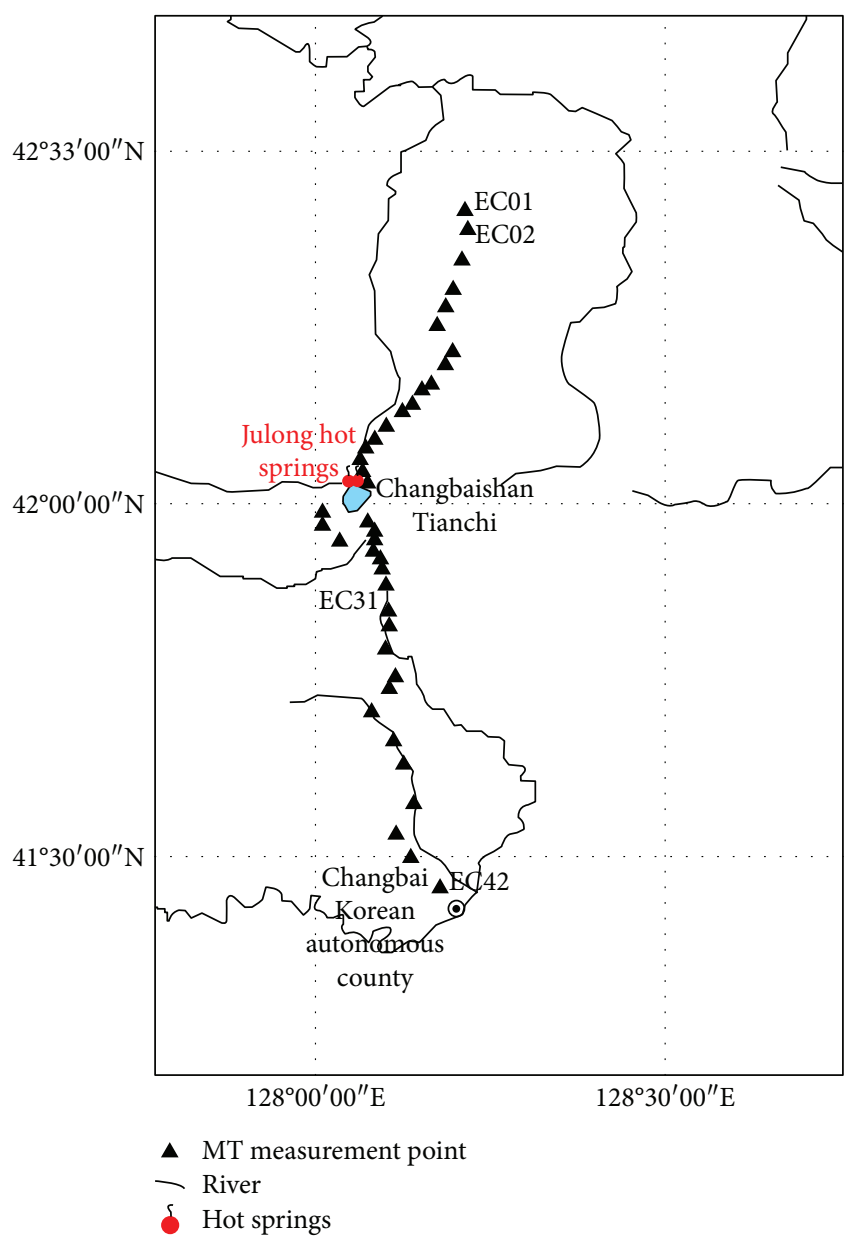

FIgURE 4: Distribution of MT station at the volcanic area in Changbai Mountain [21].

rain water samples were selected as the starting point of the reaction path. The Julong and Jinjiang hot spring water samples were selected as the ending point of the reaction path. The pyroxene hydrolysis equation was added in the PHREEQC database. And the uncertainty of the hydrogeochemistry simulation model is 0.05 . The concentration of chemistry compositions on the hydrogeochemistry simulation is as shown in Table 1.

3.5. Geophysical Exploration. Geophysical exploration together with the geological and geochemical investigation could successfully establish the existence of geothermal anomaly and the presence of shallow reservoir features. Geophysical methods are very useful, if not essential, in deciphering the geological structures, such as the highdensity resistivity (HDRT) method and magnetotelluric (MT) method.

Electrical prospecting is very important in engineering prospecting and an effective method; the direct current method of the high-density resistivity imaging method is a common method of electrical prospecting [18]. The highdensity resistivity method is a kind of array exploration method [19]. The resistivity distribution from electromagnetic surveys is interpreted in terms of water saturation of rocks, hydrothermal alteration, and presence of hydrated minerals. They are covered by basalt and trachyte on the surface around the Jinjiang hot springs. In order to get more geology information, the high-density resistivity method is used to dissect Jinjiang hot springs. Six prospecting lines were arranged with a length of each line of $590 \mathrm{~m}$. The measuring instrument is the DUK-2 high-density electrical apparatus, and each prospecting line has 60 electrodes with an electrode spacing of $10 \mathrm{~m}$. The arrangement diagram of the prospecting lines are shown in Figure 3.

As a deep geophysical technique, the magnetotelluric (MT) method is being widely used for the assessment of geothermal fields in many regions and is also the most appropriate electromagnetic technique to electrically image the subsurface structures [20]. In geothermal regions, it can provide useful information about the lateral and vertical variation of the resistivity of the subsurface. Qiu et al. [21] also analyzed the volcano magma chamber of the Changbaishan Tianchi volcano. In order to obtain more information on the stratum structure and magma chamber characteristics of Changbaishan Tianchi around the Jinjiang hot springs and Julong hot springs, a $103 \mathrm{~km}$ long magnetotelluric sounding prospecting line was arranged in Changbaishan with the direction of NE10. The point of magnetotelluric sounding prospecting was 41 whose dot pitch was $2.5 \mathrm{~km}$ (Figures 3 and 4).

In short, we present a multidisciplinary method including hydrogeochemistry, gas geochemistry, whole-rock geochemistry, stable isotope geochemistry, noble gas geochemistry, and geophysical exploration for understanding the hydrogeochemical characteristics and genesis of hydrothermal systems near the active Tianchi volcano (Changbaishan). The flow chart of the study is shown in Figure 5.

\section{Results and Discussion}

4.1. Hydrogeochemical Characteristics. The values of $\mathrm{pH}$ for the Jinjiang hot springs and Julong hot springs ranged from 6.63 to 7.05 (average value 6.77) and from 7.33 to 7.34 (average value 7.335), respectively. The values of temperature for the Jinjiang hot springs and Julong hot springs were from 36.0 to $58.0^{\circ} \mathrm{C}$ (average value $48.5^{\circ} \mathrm{C}$ ) and from 82.0 to $84.0^{\circ} \mathrm{C}$ (average value $83.0^{\circ} \mathrm{C}$ ), respectively. The temperatures of the Julong springs were higher than those of the Jinjiang hot springs, and all the hot springs belong to low-temperature geothermal resources.

The values of EC for the Jinjiang hot springs and Julong hot springs were $900-1400 \mu \mathrm{m} / \mathrm{cm}$ (average value $1150 \mu \mathrm{m} /$ $\mathrm{cm}$ ) and $1398-1400 \mu \mathrm{m} / \mathrm{cm}$ (average value $1399 \mu \mathrm{m} / \mathrm{cm}$ ), respectively. The values of total dissolved solids (TDS) for the Jinjiang hot springs and Julong hot springs were 1000.13$1708.77 \mathrm{mg} / \mathrm{L}$ (average value $1247.68 \mathrm{mg} / \mathrm{L}$ ) and $1470.53-$ $1471.79 \mathrm{mg} / \mathrm{L}$ (average value $1471.16 \mathrm{mg} / \mathrm{L}$ ), respectively.

The thermal spring samples were also enriched with trace elements such as $\mathrm{H}_{2} \mathrm{SiO}_{3}$ and $\mathrm{Sr}$. The concentration of $\mathrm{H}_{2} \mathrm{SiO}_{3}$ of the Jinjiang hot springs and Julong hot springs ranged from $136.66 \mathrm{mg} / \mathrm{L}$ to $232.28 \mathrm{mg} / \mathrm{L}$ (average value $176.26 \mathrm{mg} / \mathrm{L}$ ) and $211.5 \mathrm{mg} / \mathrm{L}$ to $211.93 \mathrm{mg} / \mathrm{L}$ (average value $211.715 \mathrm{mg} / \mathrm{L}$ ), respectively. The concentrations of $\mathrm{Sr}$ of the Jinjiang hot springs and Julong hot springs ranged 


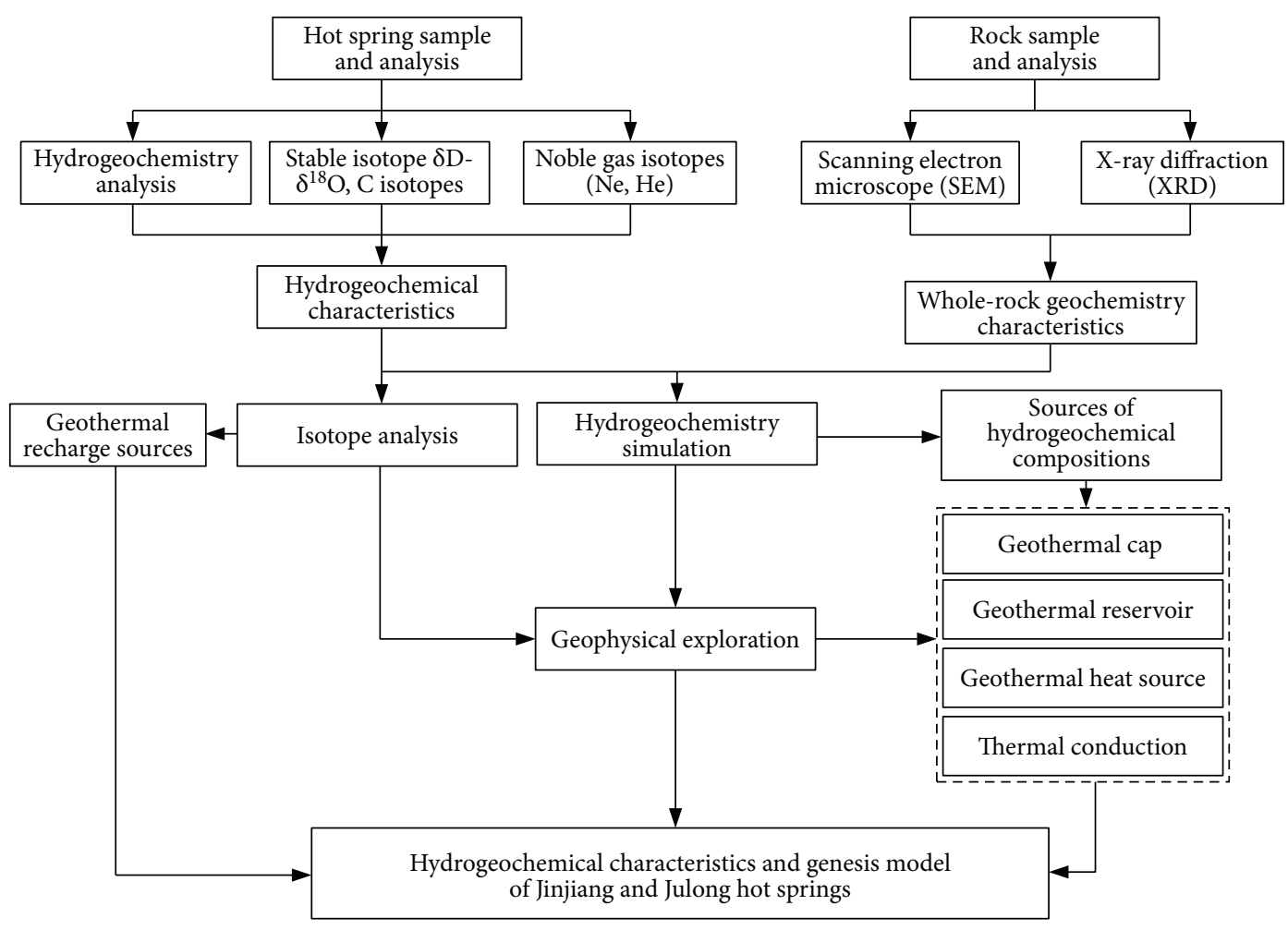

FIgURe 5: Distribution of MT station at the volcanic area in Changbai Mountain.

from 0.029 to $0.062 \mathrm{mg} / \mathrm{L}$ (average value $0.043 \mathrm{mg} / \mathrm{L}$ ) and $0.067 \mathrm{mg} / \mathrm{L}$ to $0.089 \mathrm{mg} / \mathrm{L}$ (average value $0.078 \mathrm{mg} / \mathrm{L}$ ), respectively. The types of thermal spring samples were silicate type and silicate-Sr type. The concentrations of hydrochemical data are shown in Table 2.

The distribution of ions of thermal spring samples are plotted on a Piper diagram (Figure 6). It was clearly seen that thermal spring samples were enriched in $\mathrm{Na}$ and $\mathrm{HCO}_{3}$ and were depleted in $\mathrm{Cl}$. The thermal springs were all $\mathrm{Na}-\mathrm{HCO}_{3}$ water type.

The main gas compositions of the Jinjiang hot springs and Julong hot springs are $\mathrm{CO}_{2}, \mathrm{~N}_{2}$, and $\mathrm{CH}_{4}$ (Tables 3 and 4). The percentage of $\mathrm{CO}_{2}$ of the Jinjiang hot springs and Julong hot springs is $92.25 \%-93.82 \%$ (average value 92.96\%) and 93.47\%-93.54\% (average value 93.47\%), respectively, which are both higher than $90 \%$. The average percentage of $\mathrm{N}_{2}$ of the Jinjiang and Julong hot springs is $5.16 \%$ and $5.00 \%$, respectively, and the average percentage of $\mathrm{CH}_{4}$ of the Jinjiang and Julong hot springs is $1.57 \%$ and $0.29 \%$, respectively. Gases associated with mantle magmatic activity include $\mathrm{CO}_{2}, \mathrm{He}, \mathrm{CH}_{4}$, and $\mathrm{H}_{2}$, especially $\mathrm{CH}_{4}$ and $\mathrm{He}$ [22]. The average percentages of $\mathrm{CO}_{2}, \mathrm{He}, \mathrm{CH}_{4}$, and $\mathrm{H}_{2}$ in the Jinjiang hot springs and Julong hot springs were, respectively, $94.613 \%$ and $93.818 \%$, and the average percentages of $\mathrm{He}$ and $\mathrm{CH}_{4}$ in these two hot springs were $1.575 \%$ and $0.291 \%$, respectively, which indicated that the released quantity of gases related to magmatic activity of the Jinjiang hot springs is a little higher than that of the Julong hot springs. There is a rule that $\mathrm{CO}_{2}$ release quantity from thermal springs is higher in volcanic activity and fault areas, and $\mathrm{CO}_{2}$ as an important geochemical indicator predicts the activity degree of magmatic and earthquake activity [23]. So the gas origins of the Jinjiang and Julong hot springs are related to magmatic activity. The average percentage of $\mathrm{He}$ of the Jinjiang and Julong hot springs is both $0.0015 \%$. The concentrations of He of the Jinjiang and Julong hot springs are relatively stable expect for 2003 which was a seismic activity period [24]. A lot of abiogenic $\mathrm{CH}_{4}$ is also released in the magmatic lava area [25]. The concentration of $\mathrm{CH}_{4}$ of the Julong hot springs is relatively stable, but those of Jinjiang hot springs are slowly rising in the past years [26].

\subsection{Sources of Hot Springs}

4.2.1. Recharge Sources of Hot Springs. Figure 7 shows the relationship of $\delta^{18} \mathrm{O}-\delta \mathrm{D}$ of the hot spring samples. The relationship of $\delta^{18} \mathrm{O}-\delta \mathrm{D}$ of snow and rain water samples is fall in the Changbai Mountain meteoric water line, which shows the reliability of water sample test results. The Jinjiang and Julong hot spring water samples all fall in the Changbai Mountain meteoric water offline and nearly along the global meteoric water line. Those characteristics of $\delta^{18} \mathrm{O}-\delta \mathrm{D}$ of the Jinjiang and Julong hot springs show the recharge sources from atmospheric precipitation, which are also influenced by evaporation. There was an ${ }^{18} \mathrm{O} \mathrm{drift}$ phenomenon of the hot spring samples, but the amount of drift is only about $1 \%$. The ${ }^{18} \mathrm{O}$ drift phenomenon has correlation to oxygen isotope exchange between deep geothermal water and silicate [27]. Because ${ }^{18} \mathrm{O}$ in silicate is richer than in geothermal water, the ${ }^{18} \mathrm{O}$ exchange between geothermal water and silicate can make the ${ }^{18} \mathrm{O}$ rise in geothermal water, especially in high-temperature geothermal water. 


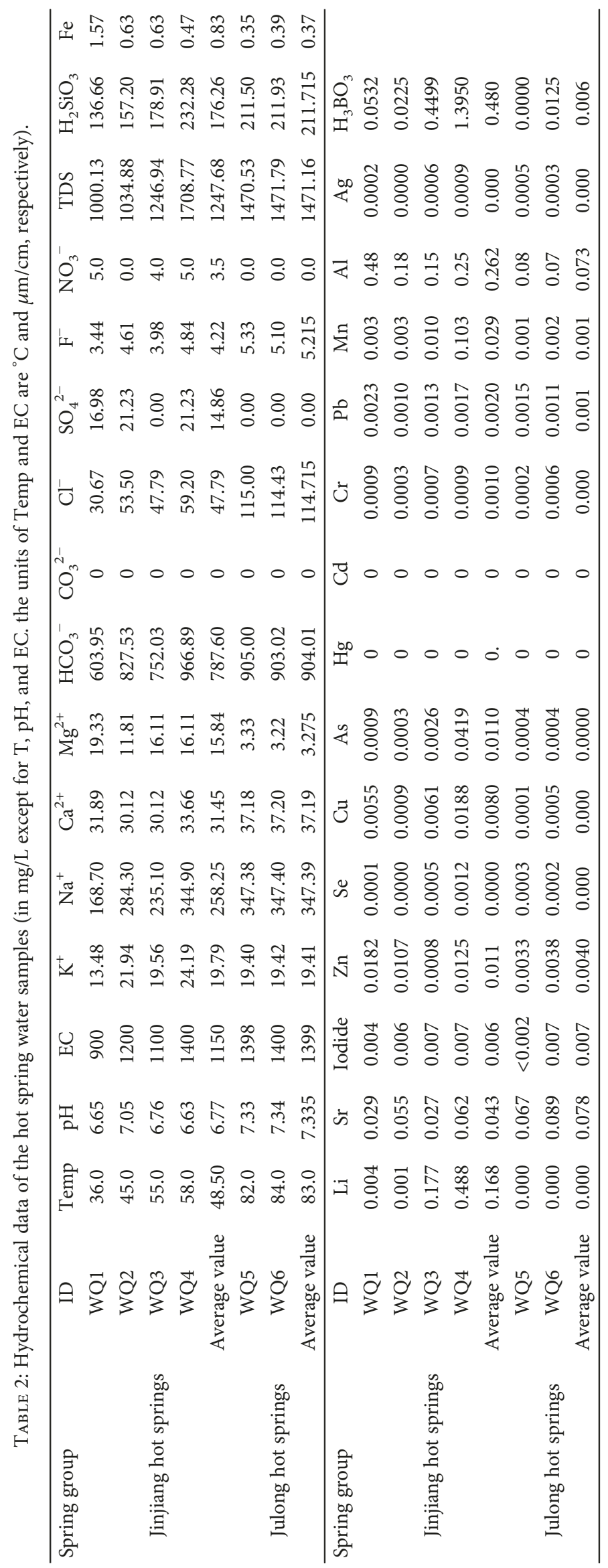




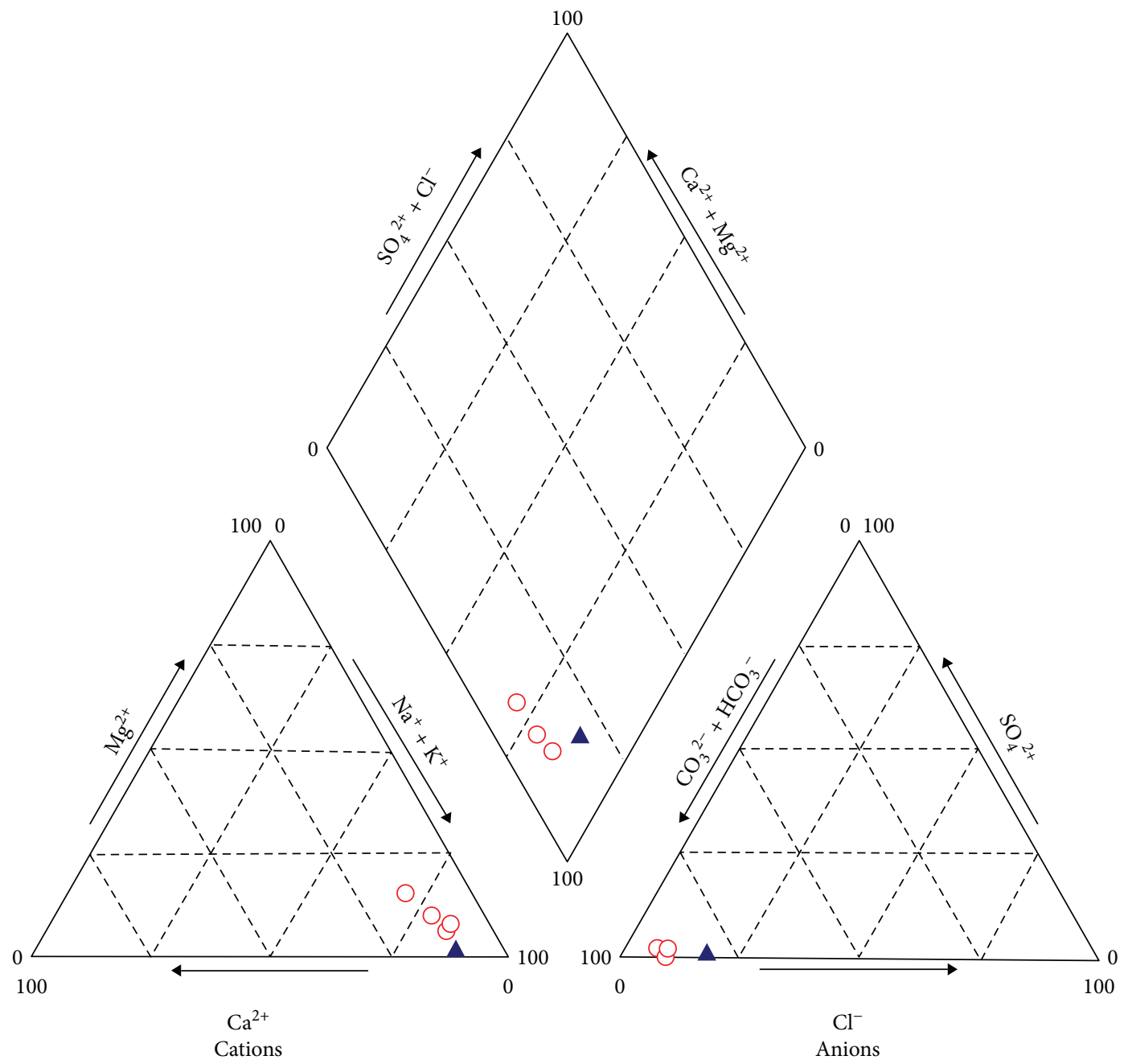

Explanation

$\bigcirc$ Jinjiang hot springs

A Julong hot springs

FIgURE 6: Piper diagram of sampled spring water.

TABLE 3: The main gas compositions of hot spring water samples (\%).

\begin{tabular}{lccccccc}
\hline Spring group & ID & $\mathrm{He}$ & $\mathrm{H}_{2}$ & $\mathrm{O}_{2}$ & $\mathrm{~N}_{2}$ & $\mathrm{CH}_{4}$ & $\mathrm{CO}_{2}$ \\
\hline \multirow{3}{*}{ Jinjiang hot springs } & WQ1 & 0.0105 & 0.0165 & 0.35 & 5.76 & 1.61 & 92.25 \\
& WQ2 & 0.0098 & 0.2908 & 0.10 & 4.55 & 1.53 & 93.52 \\
& WQ3 & 0.000098 & 0.00291 & 0.10 & 4.55 & 1.53 & 93.82 \\
& WQ4 & 0.000105 & 0.0017 & 0.35 & 5.76 & 1.61 & 92.28 \\
Julong hot springs & Average value & 0.0051 & 0.078 & 0.23 & 5.16 & 1.57 & 92.96 \\
& WQ5 & 0.0015 & 0.0295 & 1.23 & 4.95 & 0.25 & 93.54 \\
& WQ6 & 0.0015 & 0.0050 & 1.14 & 5.05 & 0.33 & 93.47 \\
& Average value & 0.0015 & 0.017 & 1.185 & 5.00 & 0.29 & 93.51 \\
\hline
\end{tabular}

The amount of ${ }^{18} \mathrm{O}$ drift is small in the study area which confirms that the springs in the study area belongs to low temperature geothermal water.

4.2.2. Gas Sources of Hot Springs. The $\delta^{13} \mathrm{CO}_{2}$ values of the Jinjiang and Julong hot springs are $-1.20 \%$, $-3.90 \%$,
$-2.78 \%$ o, $-3.19 \%$ (average value $-2.77 \%$ ); $-1.20 \%$, and $-3.90 \%$ (average value $-2.55 \%$ ). The $\mathrm{CO}_{2} /{ }^{3} \mathrm{He}$ values of the Jinjiang and Julong hot springs are $0.76 \times 10^{9}$, $1.49 \times 10^{9}, 1.65 \times 10^{9}, 0.96 \times 10^{9}$ (average value $1.22 \times 10^{9}$ ); $321.90 \times 10^{9}$, and $18.90 \times 10^{9}$ (average value $170.40 \times 10^{9}$ ). The different sources of carbon have different carbon isotope 
TABLE 4: Gas isotope (carbon and helium) characteristics of the Jinjiang and Julong hot springs.

\begin{tabular}{|c|c|c|c|c|c|c|}
\hline Spring group & ID & ${ }^{3} \mathrm{He} /{ }^{4} \mathrm{He} / 10^{-6}$ & ${ }^{20} \mathrm{Ne} /{ }^{4} \mathrm{He}$ & $\mathrm{CO}_{2} /{ }^{3} \mathrm{He} / 10^{9}$ & $\delta^{13} \mathrm{C}_{\mathrm{PDB}-\mathrm{CO} 2}(\% \mathrm{o})$ & $\delta^{13} \mathrm{C}_{\mathrm{PDB}-\mathrm{CH} 4}(\% \mathrm{o})$ \\
\hline \multirow{5}{*}{ Jinjiang hot springs } & WQ1 & 8.97 & 2.11 & 0.76 & -1.20 & -29.40 \\
\hline & WQ2 & 9.30 & 0.31 & 1.49 & -3.90 & -28.50 \\
\hline & WQ3 & 5.50 & 0.20 & 1.65 & -2.78 & -28.70 \\
\hline & WQ4 & 5.93 & 0.30 & 0.96 & -3.19 & -27.54 \\
\hline & Average value & 7.43 & 0.73 & 1.22 & -2.77 & -28.54 \\
\hline \multirow{3}{*}{ Julong hot springs } & WQ5 & 2.18 & 2.11 & 321.90 & -1.20 & -19.80 \\
\hline & WQ6 & 6.27 & 0.31 & 18.90 & -3.90 & 34.80 \\
\hline & Average value & 4.23 & 1.21 & 170.40 & -2.55 & 7.50 \\
\hline
\end{tabular}

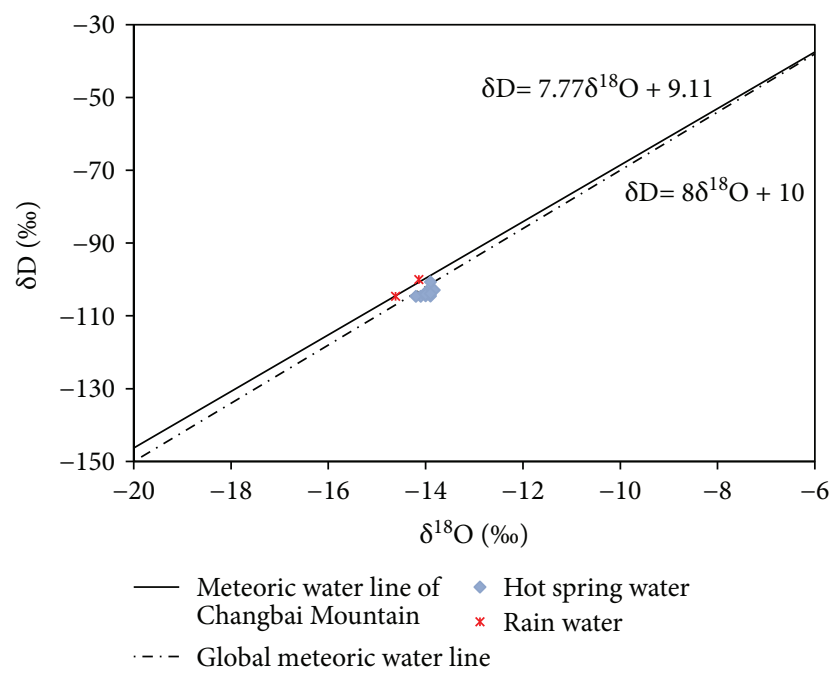

Figure 7: Relationship of $\delta^{18} \mathrm{O}-\delta \mathrm{D}$ of the hot spring samples.

values. The $\delta^{13} \mathrm{CO}_{2}$ values of the upper mantle ranged from $-9.0 \%$ o to $-4.0 \%$ o (average value $-6.5 \%$ ); the $\delta^{13} \mathrm{CO}_{2}$ values of earth's crust carbon from marine carbonate sediments are about $0 \%$, while those of organic sediments ranged from $-40 \%$ o to $-20 \%$ [ [28]. The different sources of geological fluid also have different $\mathrm{CO}_{2} /{ }^{3} \mathrm{He}$ values. The $\mathrm{CO}_{2} /{ }^{3} \mathrm{He}$ values of the mantle fluid ranged from $10^{8}$ to $10^{10}$, while those of the earth's crust fluid ranged from $10^{10}$ to $10^{12}$ [29]. So the carbon sources of the Jinjiang hot springs and Julong hot springs were the upper mantle and may have been influenced by marine carbonate sediments. The sources of ${ }^{4} \mathrm{He}$ on the earth are radioactively decayed by ${ }^{238} \mathrm{U},{ }^{235} \mathrm{U}$, and ${ }^{232} \mathrm{Th}$ in the geological history process. ${ }^{3} \mathrm{He}$ is almost produced by the mantle. The values of ${ }^{3} \mathrm{He} /{ }^{4} \mathrm{He}$ caused by the atmosphere, earth's radioactive crust, and upper mantle are, respectively, $1.39 \times 10^{-6}(1 \mathrm{Ra}), 0.0139 \times 10^{-6} \sim 0.139 \times 10^{-6}$ (0.01 Ra 0.1 Ra), and $11.12 \times 10^{-6}(8 \mathrm{Ra})$ (Allard et al., 1997). The values of ${ }^{20} \mathrm{Ne} /{ }^{4} \mathrm{He}$ and ${ }^{3} \mathrm{He} /{ }^{4} \mathrm{He}$ of the Jinjiang hot springs are $2.11,0.31,0.20$ and 0.30 (average value $0.73), 8.97 \times 10^{-6}, 9.30 \times 10^{-6}, 5.50 \times 10^{-6}$, and $5.93 \times 10^{-6}$ (average value $7.43 \times 10^{-6}$ ). The values of ${ }^{20} \mathrm{Ne} /{ }^{4} \mathrm{He}$ and ${ }^{3} \mathrm{He} /{ }^{4} \mathrm{He}$ of the Julong hot springs are 2.11 and 0.31 (average value 1.21$), 2.18 \times 10^{-6}$, and $6.27 \times 10^{-6}\left(4.23 \times 10^{-6}\right)$, which indicated that the gas sources of the Jinjiang hot springs and Julong hot springs were from the upper mantle.

\subsubsection{Hydrogeochemical Composition Sources of Hot Springs}

(1) Mineral Compositions of Rocks. The chemical composition percentage of the rock samples around the Jinjiang and Julong hot springs is shown in Table 5. The main chemical compositions are $\mathrm{SiO}_{2}, \mathrm{TiO}_{2}$, and $\mathrm{Al}_{2} \mathrm{O}_{3}$. The content percentage of $\mathrm{SiO}_{2}$ of $\mathrm{D} 1$ and $\mathrm{D} 2$ is about $50 \%$, and those of D3 and D4 are more than 50\%. By volcanic rock TAS classification, D1 and D2 belong to trachybasalt and D3 and D4 belong to trachyte.

The surface structure and mineral compositions of the rock samples were analyzed by scanning electron microscope (SEM), energy dispersive spectrum (EDS), and diffraction of $\mathrm{X}$-ray (XRD) methods. Figure 8 shows that the dominant minerals of rock samples were plagioclase with the dominant elements of $\mathrm{Na}, \mathrm{Al}, \mathrm{Si}$, and $\mathrm{O}$. There are some pyroxene and potassium feldspar, whose dominant elements are, respectively, $\mathrm{Ca}, \mathrm{Mg}, \mathrm{Al}, \mathrm{Si}$, and $\mathrm{O}$ and $\mathrm{K}, \mathrm{Al}, \mathrm{Si}$, and O. Figure 9 shows main minerals through the $\mathrm{X}$-ray diffraction method. The dominant minerals of rock samples D1, D2, D3, and D4 are plagioclase, quartz, chlorite, and pyroxene; plagioclase, quartz, feldspar, pyroxene, chlorite, calcite, and dolomite; plagioclase, feldspar, and pyroxene; and plagioclase, pyroxene, and feldspar, respectively. There are some differences about the results of mineral compositions of rock samples by scanning electron microscope (SEM), energy dispersive spectrum (EDS), and diffraction of X-ray (XRD) methods. The reason is that scanning electron microscope (SEM) and energy dispersive spectrum (EDS) determine the mineral compositions through one point of the rock samples, while X-ray diffraction determines the mineral compositions through whole rock powder samples. Through mineral composition analysis, the main mineral compositions are plagioclase, quartz, and pyroxene, as well as chlorite, calcite, fluorite, gypsum, and dolomite.

(2) Hydrogeochemical Composition Sources. Table 6 shows the results of hydrogeochemical simulation. The chemical compositions of the Jinjiang and Julong hot springs are mainly controlled by mineral hydrolysis of albite, potassium feldspar, calcium feldspar, and pyroxene. In the reaction path I (rain to the Jinjiang hot springs), the dissolving 
TABLE 5: Chemical composition percentage of rock samples around the Jinjiang and Julong hot springs.

\begin{tabular}{lcccccccccccc}
\hline Sample no. & $\mathrm{SiO}_{2}$ & $\mathrm{TiO}_{2}$ & $\mathrm{Al}_{2} \mathrm{O}_{2}$ & $\mathrm{Fe}_{2} \mathrm{O}_{3}$ & $\mathrm{FeO}$ & $\mathrm{MnO}$ & $\mathrm{MgO}$ & $\mathrm{CaO}$ & $\mathrm{Na}_{2} \mathrm{O}$ & $\mathrm{K}_{2} \mathrm{O}$ & $\mathrm{P}_{2} \mathrm{O}_{5}$ \\
\hline $\mathrm{D} 1$ & 47.76 & 13.80 & 10.38 & 3.19 & 2.22 & 9.95 & 7.83 & 1.81 & 0.17 & 47.76 & 13.80 \\
$\mathrm{D} 2$ & 51.53 & 15.41 & 11.26 & 3.69 & 1.98 & 4.62 & 7.60 & 2.11 & 0.16 & 51.53 & 15.41 \\
$\mathrm{D} 3$ & 67.97 & 13.23 & 5.41 & 4.76 & 5.40 & 0.88 & 0.10 & 0.08 & 0.16 & 67.97 & 13.23 \\
$\mathrm{D} 4$ & 62.37 & 16.53 & 6.41 & 4.94 & 5.44 & 1.82 & 0.53 & 0.43 & 0.17 & 62.37 & 16.53 \\
Average value & 57.41 & 14.74 & 8.36 & 4.15 & 3.76 & 4.32 & 4.02 & 1.11 & 0.16 & 57.41 & 14.74 \\
\hline
\end{tabular}

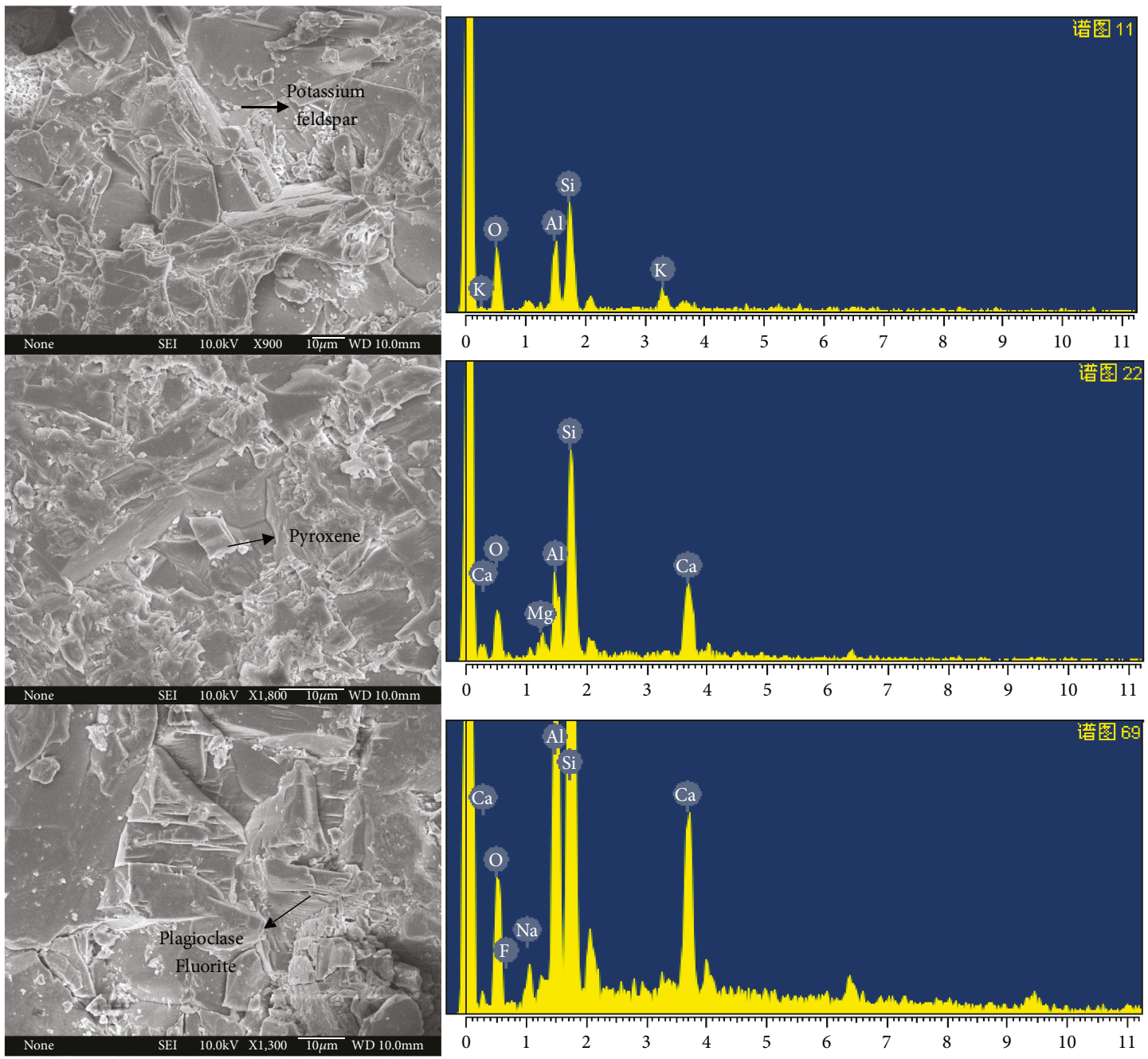

Figure 8: Scanning electron microscopic (SEM) and energy dispersion spectrum (EDS) diagrams of rock samples.

minerals are albite, potassium feldspar, calcium feldspar, pyroxene, dolomite, and gypsum. The maximum hydrolysis minerals are calcium feldspar and pyroxene with the hydrolysis amounts as $1.24 E+02$ and $6.74 E+01$, respectively. In the reaction path II (rain to the Julong hot springs), the dissolving minerals are albite, potassium feldspar, calcium feldspar, pyroxene, and dolomite. The maximum hydrolysis minerals are also calcium feldspar and pyroxene with the hydrolysis amounts as $4.41 E+02$ and $5.52 E+01$, respectively. The hot spring hydrogeochemical compositions are mainly composed of feldspar and pyroxene mineral hydrolysis.
4.3. Stratum Structure and Volcanic Magma Chamber. The data of the high-density resistivity method is inversed by Swedish RES2DINV processing software (Figure 10). The apparent resistivity values are ranged from $10 \Omega . \mathrm{m}$ to $10,000 \Omega$.m. In the six prospecting lines, high-resistance media are mainly distributed in the surface between 40 and $50 \mathrm{~m}$, which includes Cenozoic basalt and trachyte. There is a wide range of the low-resistance zone below the surface of $50 \mathrm{~m}$ in the six prospecting lines, which includes volcanic breccia, sand, and gravel. There is a clear boundary line between the low-resistance zone and the high-resistance zone, which infers a fracture. The low-resistance zone is 

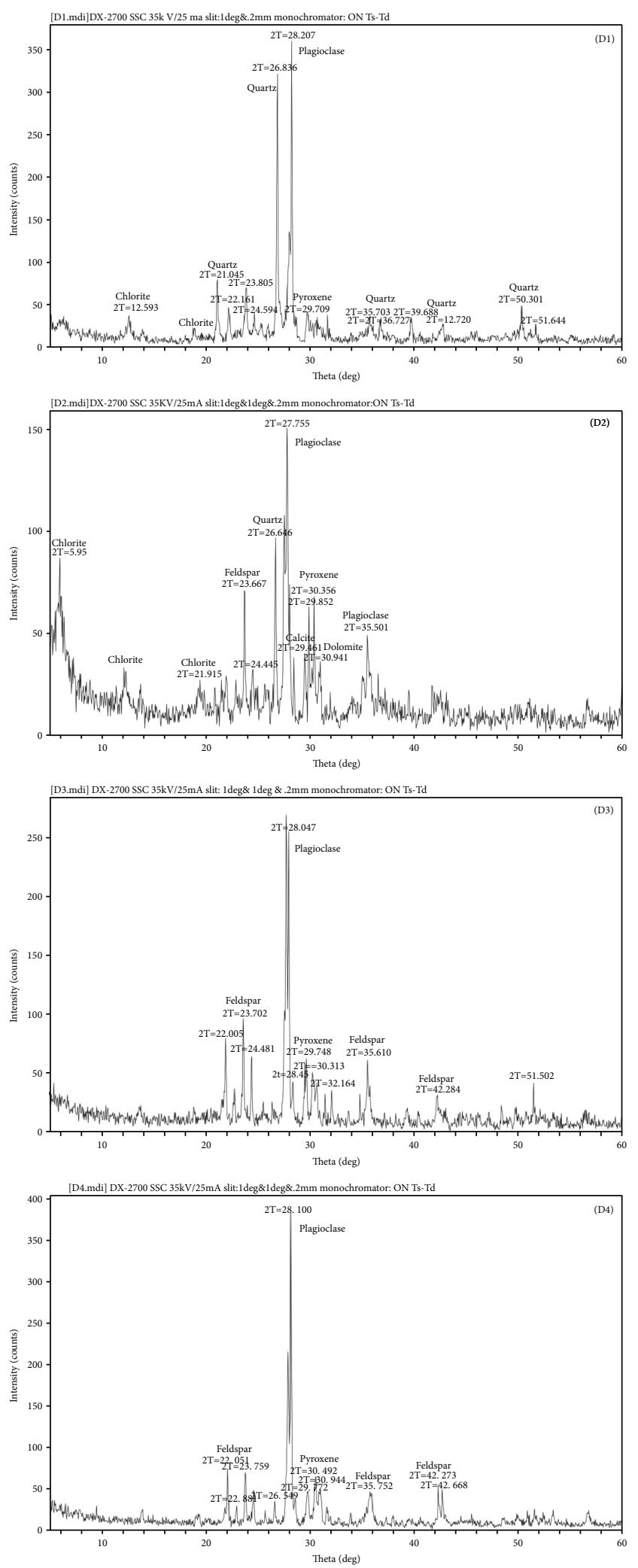

FIGURE 9: Diagram of X-ray diffraction of rock samples.

mainly a geothermal reservoir and aquifer. So the cap rocks of the Jinjiang hot springs are composed of trachyte, basalt, andesite, and andesitic tuff; the geothermal reservoir is a fracture zone with the lithology of volcanic breccia, sand, and gravel.

The results of the magnetotelluric (MT) method are 2D inversed by NLCG 2D inversion technique (Figure 11). There is an obvious vertical volcano magma channel at the bottom of the Changbai Mountain Tianchi crater, and the magma channel is closed at the depth of about $5-8 \mathrm{~km}$. At the bottom of the crater, near the north direction about $7 \mathrm{~km}$ deep, there exists an obvious low-resistance body where the resistivity is less than $10 \Omega$.m and is connected to the magma channel. It is inferred that it may be a developing magma chamber in a shallow surface. The abnormal region is between stations EC07 and EC09 near the entrance gate of Changbai Mountain, and between EC04 and EC05 stations, there are two obvious nearly vertical low-resistivity zones existing at the depth of about $7-17 \mathrm{~km}$, and connecting with the lowresistance body directly below, it is inferred that the lowresistivity zone contains the magma. As the depth increases, the crust low-resistivity anomaly bodies are widely developed at the depth of $13 \mathrm{~km}$ to $30 \mathrm{~km}$ north to the position of $20 \mathrm{~km}$ south from the Tianchi volcano, which may be the active magma chamber. So there is a magma chamber below the Tianchi volcano.

4.4. Hot Spring Genesis Conceptual Model. The genetic model for the Jinjiang hot springs is as follows: the heat source is a magma body below the north of the Changbai Mountain Tianchi crater with a distance of $7-17 \mathrm{~km}[30,31]$. And the heat is migrated in the form of thermal conduction manner. The cap rocks are composed of trachyte of Baitoushan formation, basalt of Junjianshan formation, andesite of Changbai formation. The geothermal reservoir is a fracture zone with the lithology of volcanic breccia, sand, and gravel. Hot spring water is mainly supplied by precipitation and is also influenced by evaporation. The Jinjiang hot springs are exposed on the surface along the fault zone by deep circulation with a distance of $4.00-4.56 \mathrm{~km}$. In deep circulation, the hydrolysis of feldspar and pyroxene produces chemical compositions, and the gas compositions are derived from the mantle (Figure 12).

The genetic model for the Julong hot springs is as follows: the heat source is also the magma body. And the heat is also migrated in the form of a thermal conduction manner. The cap rocks are composed of trachyte of Baitoushan formation, basalt of Junjianshan formation, and andesite of Changbai formation. The geothermal reservoir is a fracture zone with the lithology of volcanic breccia and marble. Hot spring water is mainly supplied by precipitation and is also influenced by evaporation. The Julong hot springs are exposed on the surface along the fault zone by deep circulation and heated by the magma heat source. In deep circulation, the hydrolysis of feldspar and pyroxene produces chemical compositions, and the gas compositions are derived from the earth's radioactive crust (Figure 13).

\section{Conclusions}

The temperatures of the Jinjiang hot springs and Julong hot springs were from 36.0 to $58.0^{\circ} \mathrm{C}$ (average value $48.5^{\circ} \mathrm{C}$ ) and 
TABLE 6: The results of the hydrogeochemical simulation.

\begin{tabular}{lcccccc}
\hline Reaction path & Albite & Potassium feldspar & Calcium feldspar & Pyroxene & Quartz & Calcite \\
I & $+2.16 E-02$ & $+3.32 E-04$ & $+1.24 E+02$ & $+6.74 E+01$ & $/$ & $-3.61 E+02$ \\
II & $+1.73 E-02$ & $+3.40 E-04$ & $+4.41 E+02$ & $+5.52 E+01$ & $/$ & $-9.93 E+02$ \\
Reaction path & Dolomite & Gypsum & Kaolinite & Gibbsite & Ca montmorillonite & Chlorite \\
I & $+1.81 E-04$ & $+5.63 E-03$ & $-7.86 E+01$ & $/$ & $-6.36 E+01$ & $-4.96 E+01$ \\
II & $+4.97 E-04$ & $-7.26 E-04$ & $-3.31 E+02$ & $/$ & $-2.68 E+02$ \\
\hline
\end{tabular}

“+” represents minerals dissolving, "-" represents mineral precipitation, and "” represents no reaction.
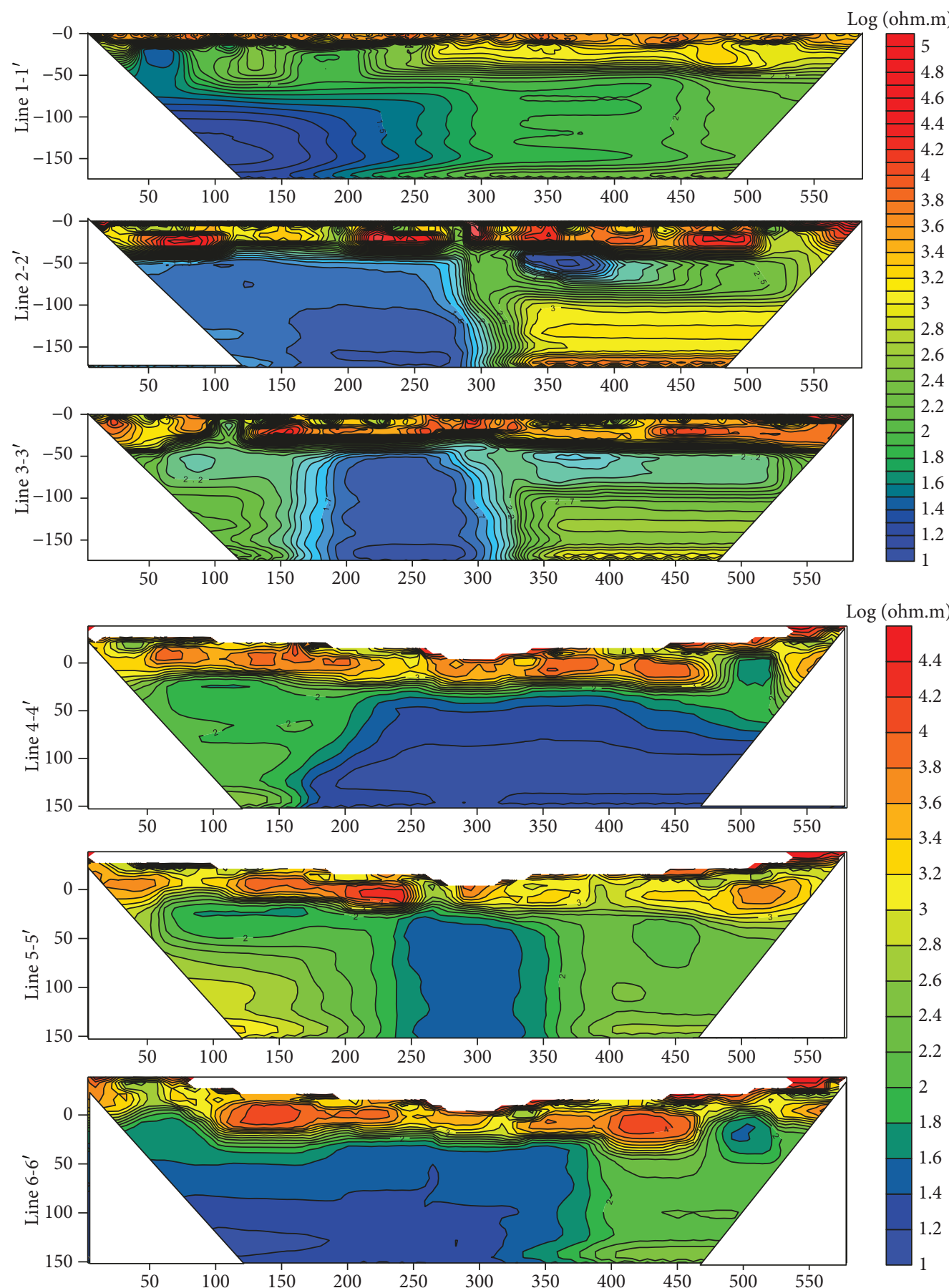

FIGURE 10: The results of high-density resistivity method (HDRT). 


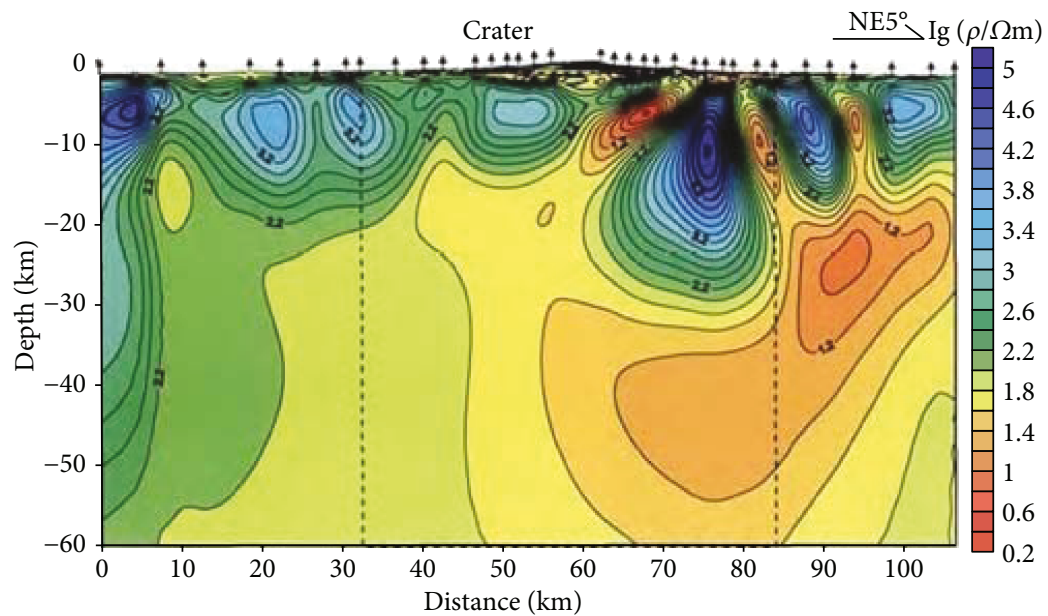

FIgURE 11: Two-dimensional MT inversion result at the volcanic area in Changbai Mountain (Qiu, 2014).

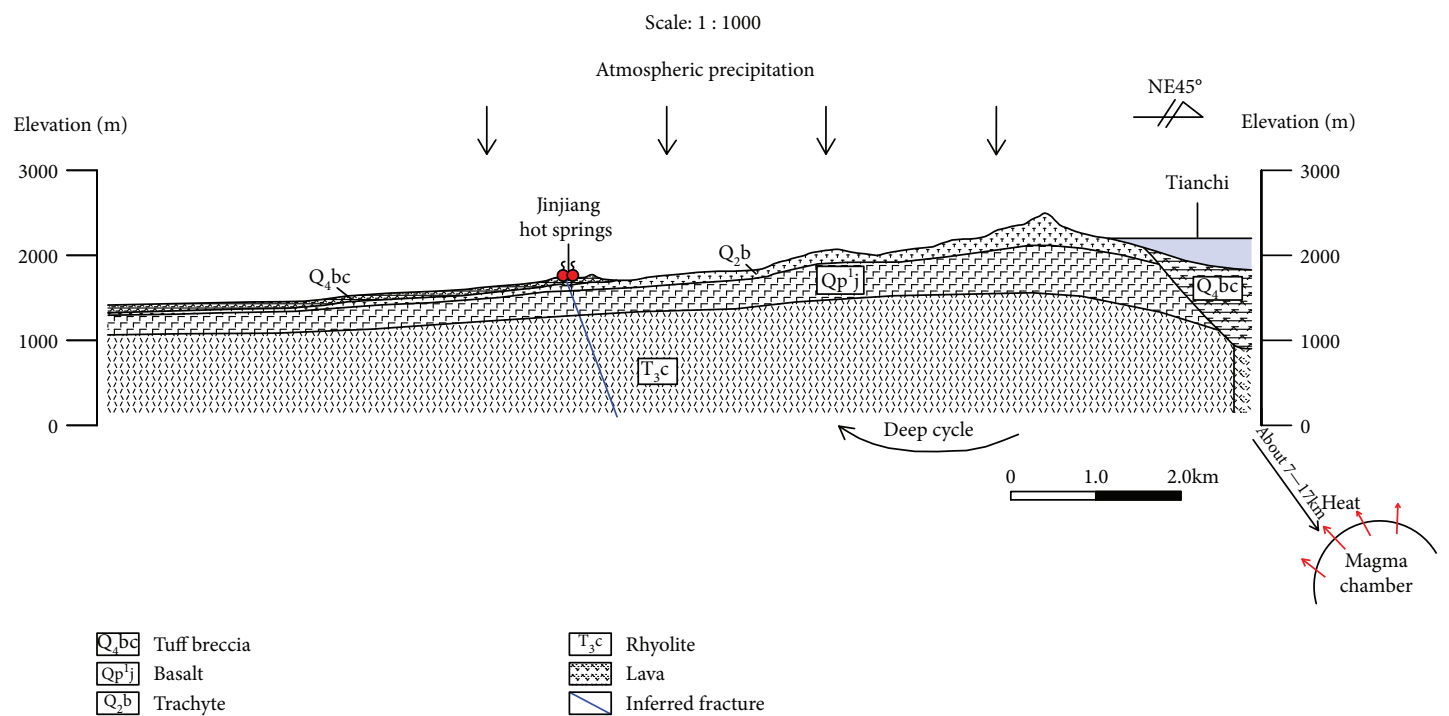

FIGURE 12: The genesis conceptual model of the Jinjiang hot springs.

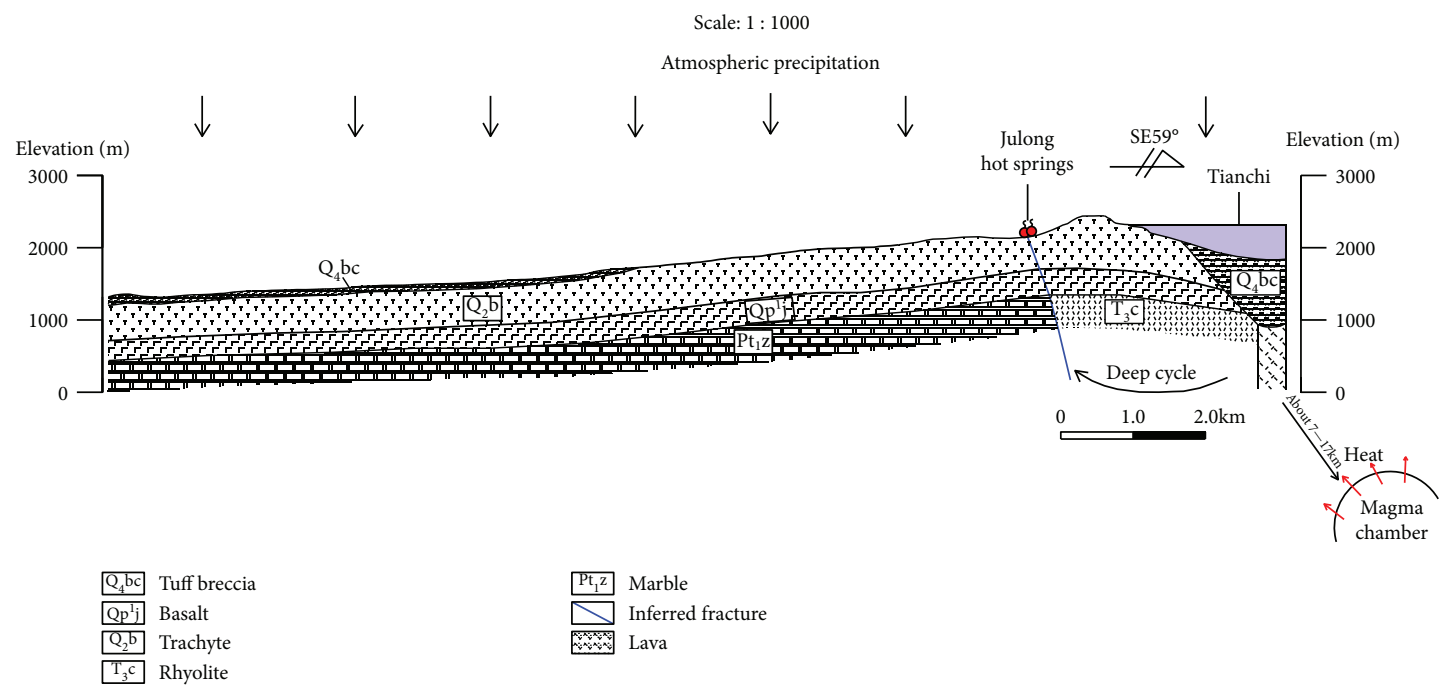

Figure 13: The genesis conceptual model of the Julong hot springs. 
from 82.0 to $84.0^{\circ} \mathrm{C}$ (average value $83.0^{\circ} \mathrm{C}$ ), respectively. All the hot springs belong to low-temperature geothermal resources. The water chemical types of hot spring water were $\mathrm{Na}-\mathrm{HCO}_{3}$, with high concentrations of $\mathrm{Na}^{+}$and $\mathrm{HCO}_{3}{ }^{-}$and enriched in trace elements such as $\mathrm{H}_{2} \mathrm{SiO}_{3}$ and $\mathrm{Sr}$. The main gas composition of the Jinjiang hot springs and Julong hot springs is $\mathrm{CO}_{2}, \mathrm{~N}_{2}$, and $\mathrm{CH}_{4}$. The recharge sources of hot springs are atmospheric precipitation and are also influenced by evaporation, and the chemical compositions are produced by feldspar and pyroxene mineral hydrolysis. The gas composition sources of the Jinjiang and Julong hot springs are derived from the upper mantle.

The genetic model for the Jinjiang hot springs and Julong hot springs are as follows: the heat source of both is the magma body below the north of the Changbai Mountain Tianchi crater with a distance of $7-17 \mathrm{~km}$. The heat is migrated in the form of a thermal conduction manner. The cap rocks are both composed of trachyte of Baitoushan formation, basalt of Junjianshan formation, and andesite of Changbai formation. The geothermal reservoir is a fracture zone with the lithology of volcanic breccia, sand, and gravel and volcanic breccia and marble, respectively.

\section{Data Availability}

The measured data used to support the findings of this study are included within the article.

\section{Conflicts of Interest}

The authors declare that they have no conflicts of interest.

\section{Acknowledgments}

This work was financially supported by the major scientific and technological projects of Jilin Province (07731441GNJL00390), the Scientific Research Initiation Funds for PhD Scholars (BQ2017011), Hebei Province Water Conservancy Science and Technology Plan Projects (2017-59), the Youth Natural Science Fund Project of Hebei Province (D2018403040), the Youth Foundation of Hebei Province Department (QN2017026), and the China Postdoctoral Science Fund (2018M631874).

\section{References}

[1] M. A. Armienta, R. Rodríguez, N. Ceniceros et al., "Groundwater quality and geothermal energy. The case of Cerro Prieto Geothermal Field. México," Renewable Energy, vol. 63, pp. 236-254, 2014.

[2] J. K. Björke, A. Stefánsson, and S. Arnórsson, "Surface water chemistry at Torfajökull, Iceland-quantification of boiling, mixing, oxidation and water-rock interaction and reconstruction of reservoir fluid composition," Geothermics, vol. 58, pp. 75-86, 2015.

[3] Y. M. Wang, W. B. Zhou, H. C. Yu, T. YW, W. CZ, and S. JC, "Application of hot spring gas monitoring in researching active volcano," Seismological Research of Northeast China, vol. 25, no. 2, pp. 63-66, 2009.
[4] H. Q. Wei, Y. Wang, J. Y. Jin, L. Gao, S. H. Yun, and B. Jin, "Timescale and evolution of the intracontinental Tianchi volcanic shield and ignimbrite-forming eruption, Changbaishan, Northeast China," Lithos, vol. 96, no. 1-2, pp. 315-324, 2007.

[5] H. Q. Wei, G. M. Liu, and J. Gill, "Review of eruptive activity at Tianchi volcano, Changbaishan, Northeast China: implications for possible future eruptions," Bulletin of Volcanology, vol. 75, no. 4, pp. 706-720, 2013.

[6] A. Franco and M. Vaccaro, "An integrated "Reservoir-Plant" strategy for a sustainable and efficient use of geothermal resources," Energy, vol. 37, no. 1, pp. 299-310, 2012.

[7] I. K. G. Boothroyd, "Ecological characteristics and management of geothermal systems of the Taupo Volcanic Zone, New Zealand," Geothermics, vol. 38, no. 1, pp. 200-209, 2009.

[8] W. Mannington, M. O'Sullivan, and D. Bullivant, "Computer modelling of the Wairakei-Tauhara geothermal system, New Zealand," Geothermics, vol. 33, no. 4, pp. 401-419, 2004.

[9] F. Händel, R. Liedl, J. Fank, and G. Rock, "Regional modeling of geothermal energy systems in shallow aquifers: the Leibnitzer Feld case study (Austria)," Environmental Earth Sciences, vol. 70, no. 8, pp. 3433-3446, 2013.

[10] H. Saibi, J. Nishijima, T. Hirano, Y. Fujimitsu, and S. Ehara, "Relation between structure and low-temperature geothermal systems in Fukuoka city, southwestern Japan," Earth, Planets and Space, vol. 60, no. 8, pp. 821-826, 2008.

[11] C. M. Lichoro, K. Arnason, and W. Cumming, "Resistivity imaging of geothermal resources in northern Kenya rift by joint 1D inversion of MT and TEM data," Geothermics, vol. 68 , pp. 20-32, 2017.

[12] C. L. Arora, H. Singh, L. K. Das, T. K. Ghatak, R. P. Singh, and A. Hakim, "Geophysical exploration of the Puga Valley geothermal field, Ladakh District, Jammu and Kashmir State," Special Publication Geological Survey India, vol. 2, pp. 631646, 1983.

[13] Z. F. Zeng, X. Chen, J. Li, L. TL, and Z. LH, “Advancement of geothermal geophysics exploration," Progress in Geophysics, vol. 27, no. 1, pp. 168-178, 2012.

[14] G. A. Newman, E. Gasperikova, G. M. Hoversten, and P. E. Wannamaker, "Three-dimensional magnetotelluric characterization of the Coso geothermal field," Geothermics, vol. 37, no. 4, pp. 369-399, 2008.

[15] APHA, Standard Methods for the Examination of Water and Wastewater, American Public Health Association, Washington, 20th edition, 1998.

[16] L. Calmbach, Aquachem Computer Code-Version 3.7.42, Waterloo Hydrogeologic, Waterloo, ON, Canada, 1997.

[17] D. L. Parkhurst and C. A. J. Appelo, User's Guide to PHREEQC (Version 2)-a Computer Program for Speciation, Batch-Reaction, One-Dimensional Transport, and Inverse Geochemical Calculations, U.S. Geological Survey Water-Resources Investigations Report, 1999, 99-4259:312.

[18] S. Davydycheva, N. Rykhlinsky, and P. Legeido, "An electrical prospecting method for oil search using the induced polarization effect," in SEG Technical Program Expanded Abstracts, pp. 604-607, Society of Exploration Geophysicists, 2004.

[19] M. Hui, J. Guang, and Z. Li, "Application of high density resistivity method in accuracy of goaf detection," Global Geology, vol. 14, no. 2, pp. 110-114, 2011. 
[20] K. Mohan, G. P. Kumar, P. Chaudhary et al., "Magnetotelluric investigations to identify geothermal source zone near Chabsar hotwater spring site, Ahmedabad, Gujarat, Northwest India," Geothermics, vol. 65, pp. 198-209, 2017.

[21] G. G. Qiu, F. G. Fei, H. Fang, and D. W. Bai, "Analysis of magma chamber at the Tianchi volcano area in Changbai Mountain," Geophysics, vol. 57, no. 10, pp. 3466-3477, 2014.

[22] Z. G. Shangguan and C. Z. Wu, "Geochemical features of magmatic gases in the regions of dormant volcanoes in China," Acta Petrologica Sinica, vol. 24, no. 11, pp. 2638-2646, 2008.

[23] J. du, C. Liu, B. Fu et al., "Variations of geothermometry and chemical isotopic compositions of hot spring fluids in the Rehai geothermal field, Southwestern China," Journal of Volcanology and Geothermal Research, vol. 142, no. 3-4, pp. 243-261, 2005.

[24] M. L. Zhang, Z. F. Guo, Y. Sano, Z. Cheng, and L. Zhang, "Stagnant subducted Pacific slab-derived $\mathrm{CO}_{2}$ emissions: insights into magma degassing at Changbaishan volcano, NE China," Journal of Asian Earth Sciences, vol. 106, pp. 49-63, 2015.

[25] G. Etiope, Natural Gas Seepage: the Earth's Hydrocarbon Degassing, Springer, Switzerland, 2015.

[26] T. Li, J. Q. Liu, X. B. Wang et al., "Geochemical characteristics and genesis of gases from Tianchi Volcanic Springs, Changbai Mountains, Jilin, China," Bulletin of Mineralogy, Petrology and Geochemistry, vol. 34, no. 6, pp. 1192-1202, 2015.

[27] Z. H. Pang, Z. C. Fan, and J. Y. Wang, "The study on stable oxygen and hydrogen isotopes in the Zhengzhou basin hydrothermal system," Acta Petrologica Sinica, vol. 4, pp. 75-84, 1990.

[28] Z. R. Cheng, Z. F. Guo, M. L. Zhang, and L. Zhang, "Carbon dioxide emission from Tengchong Cenozoic volcanic field, Yunnan Province, Southwest China," Acta Petrologica Sinica, vol. 30, no. 12, pp. 3657-3670, 2014.

[29] E. Roulleau, Y. Sano, N. Takahata, S. Kawagucci, and H. Takahashi, "He, N and C isotopes and fluxes in Aira caldera: comparative study of hydrothermal activity in Sakurajima volcano and Wakamiko crater, Kyushu, Japan," Journal of Volcanology and Geothermal research, vol. 258, pp. 163175, 2013.

[30] R. Kyong-Song, J. O. S. Hammond, K. Chol-Nam et al., "Evidence for partial melt in the crust beneath Mt. Paektu (Changbaishan), Democratic People's Republic of Korea and China," Science Advances, vol. 2, no. 4, article e1501513, 2016.

[31] S. Kim, H. Tkalčić, and J. Rhie, "Seismic constraints on magma evolution beneath Mount Baekdu (Changbai) volcano from transdimensional Bayesian inversion of ambient noise data," Journal of Geophysical Research: Solid Earth, vol. 122, no. 7, pp. 5452-5473, 2017. 

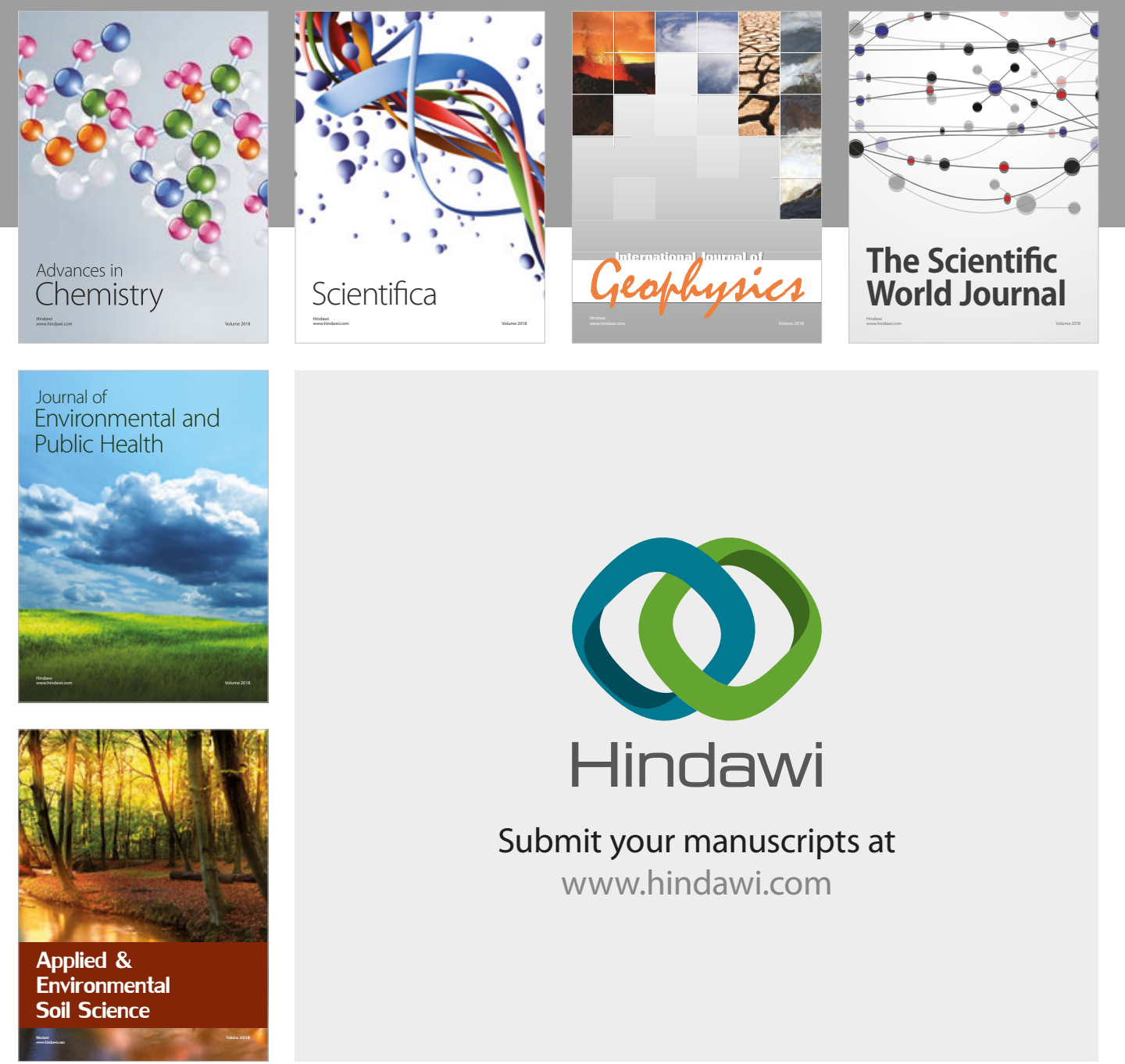

The Scientific

\section{World Journal}
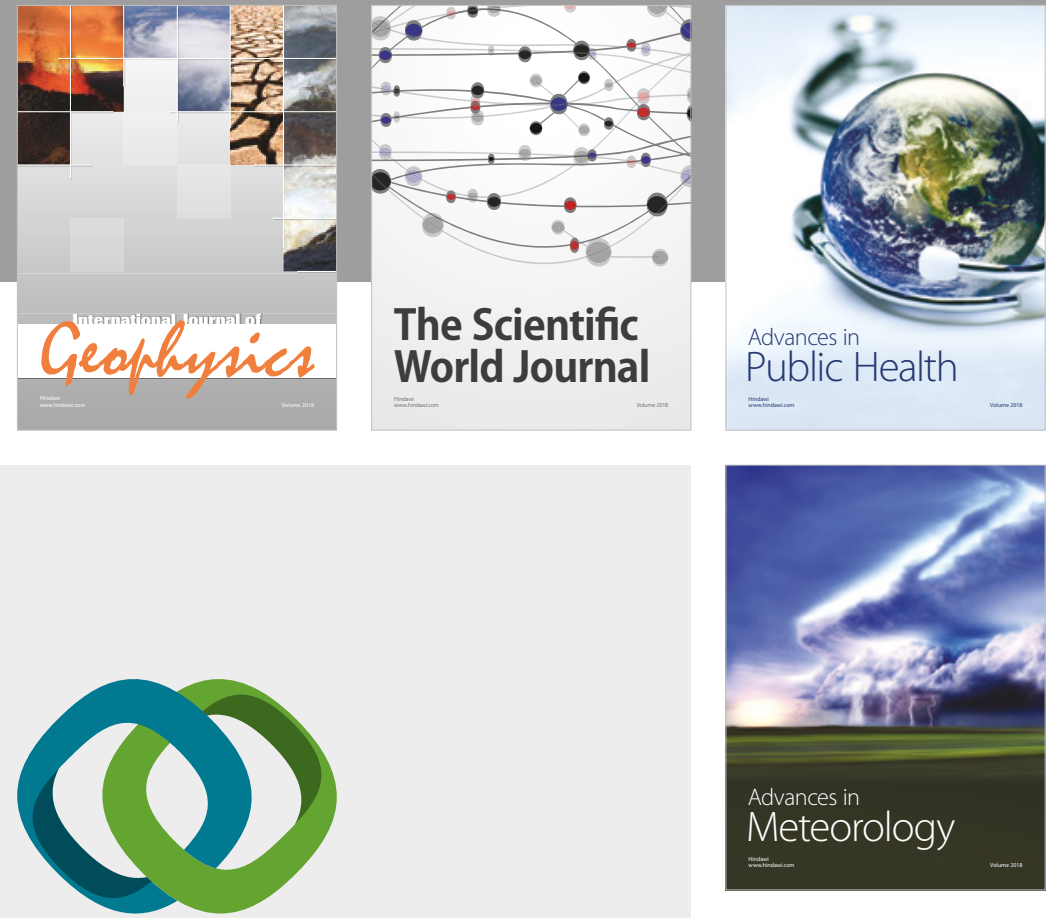

Advan

Public Health

\section{Hindawi}

Submit your manuscripts at

www.hindawi.com
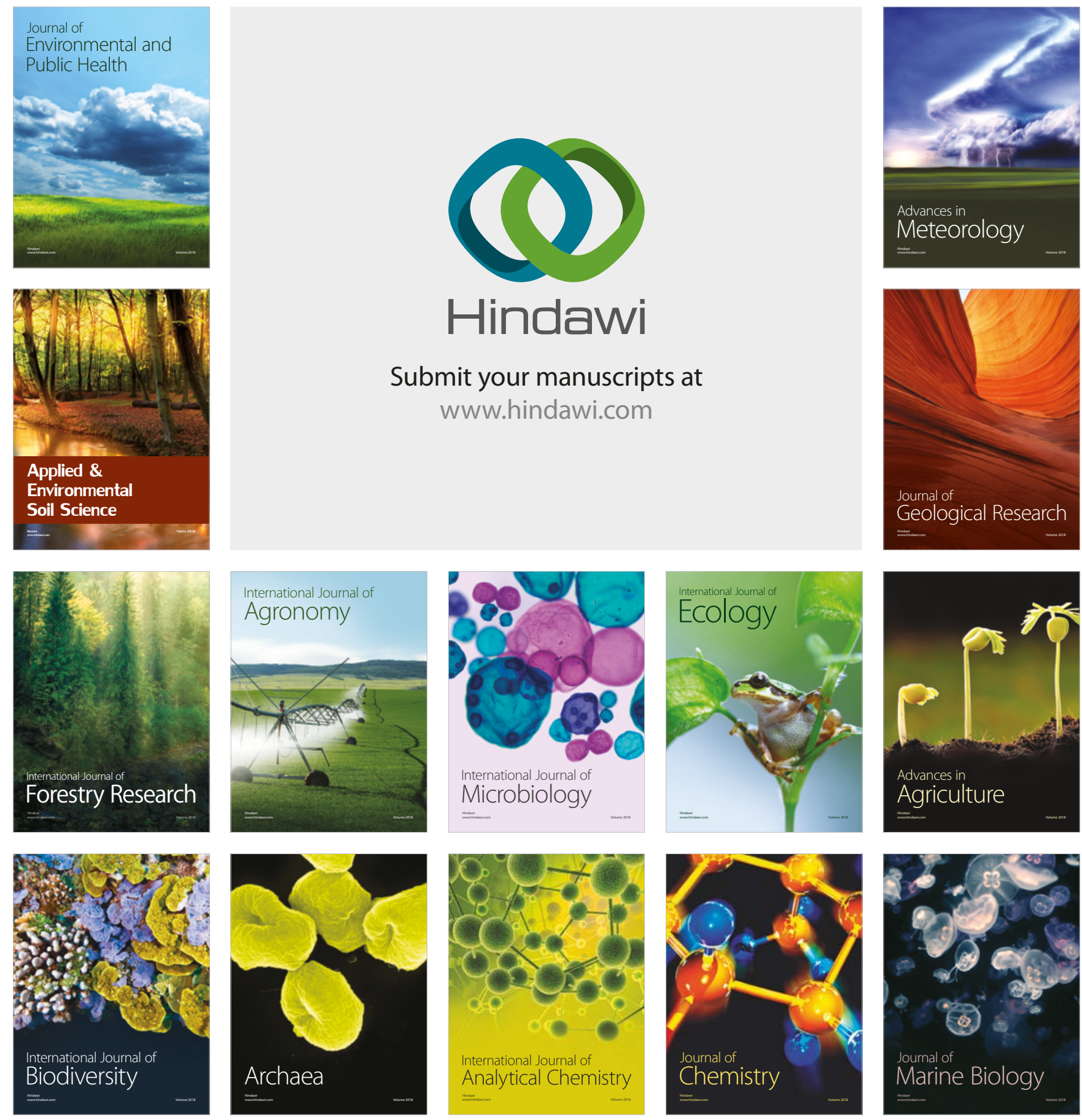